\title{
Gene Modified CAR-T Cellular Therapy for Hematologic Malignancies
}

\author{
Wen-Ying Lin ${ }^{1}$, Hsin-Hui Wang ${ }^{2,3,4}$, Yi-Wei Chen ${ }^{5,6}$, Chun-Fu Lin ${ }^{6,7}$, Hueng-Chuen Fan ${ }^{8,9,10,11}$ \\ and Yi-Yen Lee ${ }^{6,7,12, *}$ \\ 1 Department of Internal Medicine, Taipei Veterans General Hospital, Taipei 11217, Taiwan; \\ sincesnow@gmail.com \\ 2 Department of Pediatrics, Division of Pediatric Immunology and Nephrology, \\ Taipei Veterans General Hospital, Taipei 11217, Taiwan; hhwang@vghtpe.gov.tw \\ 3 Department of Pediatrics, Faculty of Medicine, School of Medicine, National Yang-Ming University, \\ Taipei 11221, Taiwan \\ 4 Institute of Emergency and Critical Care Medicine, School of Medicine, National Yang-Ming University, \\ Taipei 11221, Taiwan \\ 5 Division of Radiation Oncology, Department of Oncology, Taipei Veterans General Hospital, \\ Taipei 11217, Taiwan; chenyw@vghtpe.gov.tw \\ 6 School of Medicine, National Yang-Ming University, Taipei 11221, Taiwan; cf_lin@vghtpe.gov.tw \\ 7 Department of Neurosurgery, Neurological Institute, Taipei Veterans General Hospital, Taipei 11217, Taiwan \\ 8 Department of Pediatrics, Tungs' Taichung Metroharbor Hospital, Wuchi, Taichung 435403, Taiwan; \\ wylin17@vghtpe.gov.tw \\ 9 Department of Medical Research, Tungs' Taichung Metroharbor Hospital, Wuchi, Taichung 435403, Taiwan \\ 10 Department of Life Sciences, National Chung Hsing University, Taichung 402, Taiwan \\ 11 Department of Rehabilitation, Jen-Teh Junior College of Medicine, Nursing and Management, \\ Miaoli 356, Taiwan \\ 12 Division of Pediatric Neurosurgery, Department of Neurosurgery, Neurological Institute, \\ Taipei Veterans General Hospital, Taipei 11217, Taiwan \\ * Correspondence: yylee6@vghtpe.gov.tw; Tel.: +886-2-28757491; Fax: +886-2-28757588
}

Received: 20 October 2020; Accepted: 15 November 2020; Published: 17 November 2020

check for updates

\begin{abstract}
With advances in the understanding of characteristics of molecules, specific antigens on the surface of hematological malignant cells were identified and multiple therapies targeting these antigens as neoplasm treatments were developed. Among them, chimeric antigen receptor (CAR) T-cell therapy, which got United States Food and Drug Administration (FDA) approval for relapsed/refractory $(r / r)$ diffuse large B-cell lymphoma (DLBCL) as well as for recurrent acute lymphoblastic leukemia (ALL) within the past five years, and for $r / r$ mantle cell lymphoma (MCL) this year, represents one of the most rapidly evolving immunotherapies. Nevertheless, its applicability to other hematological malignancies, as well as its efficacy and persistence are fraught with clinical challenges. Currently, more than one thousand clinical trials in CAR T-cell therapy are ongoing and its development is changing rapidly. This review introduces the current status of CAR T-cell therapy in terms of the basic molecular aspects of CAR T-cell therapy, its application in hematological malignancies, adverse reactions during clinical use, remaining challenges, and future utilization.
\end{abstract}

Keywords: acute lymphoblastic leukemia (ALL); diffuse large B cell lymphoma (DLBCL); multiple myeloma (MM); chimeric antigen receptor (CAR)-T cells; gene modified-based cellular platform; immunotherapy 


\section{Introduction}

\subsection{History of Immunotherapy in Hematological Malignancy}

Hematological malignancies, such as Hodgkin disease, and leukemia, were first described in the 19th century [1]. Since then, numerous regimens of therapies, mostly chemotherapy, were developed over the past two centuries. However, allogeneic hematopoietic stem cell transplantation (allo-HSCT), which transfuses a matched donor's peripheral blood or bone marrow stem cells to a recipient who has received conditioned chemotherapy to kill off most cancer cells, seems to be the only curative treatment or the regimen milestones in many hematological malignancies [2]. Indeed, allo-HSCT, first performed in 1968, is the precursor of immunotherapies, as it allows immune cells from the donor to recognize and demolish "non-self" cells [3]. Recently, with the discovery of the molecular basis of tumor cells, multiple immunotherapies for cancers including monoclonal antibodies, antibody-drug conjugates, bispecific T-cell engagers, checkpoint inhibitors, and chimeric antigen receptor (CAR) T-cell therapies have evolved and have expeditiously acquired approval from the United States Food and Drug Administration (FDA) [3]. Among them, CAR T-cell therapy for selected hematological malignancies provides a nascent platform for cancer treatments. Herein, we provide an overview of the applications of CAR T-cell therapy to hematologic malignancies, with discussions of its limitations and future perspectives.

\subsection{Molecular Structure of CAR T-Cell}

CARs are artificial recombination proteins that contain three main parts-an extracellular antigen-recognition domain, a transmembrane domain, and an intracellular tyrosine containing activation motifs $[4,5]$. The part outside cell membrane is an antigen-targeting moiety purified from a monoclonal antibody, consisting of a single-chain variable fragment $(\mathrm{scFv})$, a fusion protein of the variable regions of heavy and light chains. Once bound to tumor antigens, it is responsible for triggering T-cell activation and leads to cytokine release, cytolytic degranulation, and T-cell proliferation [6]. As for the intracellular domain linking to extracellular domain through a transmembrane domain, it determines the quality, strength, and persistence of a T-cell response to tumor antigens [7]. Different fragments are incorporated for corresponding malignancies on the outer domains, while the inner domain provides the space for improving the efficacy of CAR T-cell therapies and yields five generations of CARs to date (Figure 1). The initial generation of CARs, whose endodomain contains only CD3- $\zeta$ chain or FceRI $\gamma$, supports inadequate T-cell expansion, a short in vivo life span and insufficiently secreted cytokines [8-10]. An intracellularly costimulatory domain CD28 [11,12] or 4-1BB [13] was then added to generate the second generation of CARs, which ameliorated T-cell proliferation, response to tumor antigens, and in vivo persistence [14]. To achieve higher potency, CD28 and 4-1BB were combined together, and yielded the third generation $[15,16]$. As for the fourth generation, in addition to adoptive immunity, interleukin-12 (IL-12) or other cytokines (such as IL-8, 9, 15, and 18) was tethered to the endodomain of the second generation, in an attempt to activate innate immunity at the same time. This manipulation led to the recruitment of tumor infiltrating T-cells (TILs) and natural killer cells that were able to eliminate antigen-negative cancer cells [17]. This amalgamation is termed as T-cell redirected for universal cytokine-mediated killing (TRUCKs) [14]. Activating cytokines not only modifies the tumor microenvironments but also results in prolong activation of CARs and protects T-cell from activation-induced cell death. This finding is currently in its early phase of clinical trials [18]. Recently, fifth generation of CARs was proposed as a product of insertion of an IL- 2 receptor $\beta$-chain domain, with a binding site for the transcription factor STAT3. This can induce robust cytokine (JAK-STAT3/5) signaling in the targeted tumor tissues and reduce systemic side effects [19], thereby broadening the use of CAR T-cell therapy to a variety of other diseases. 


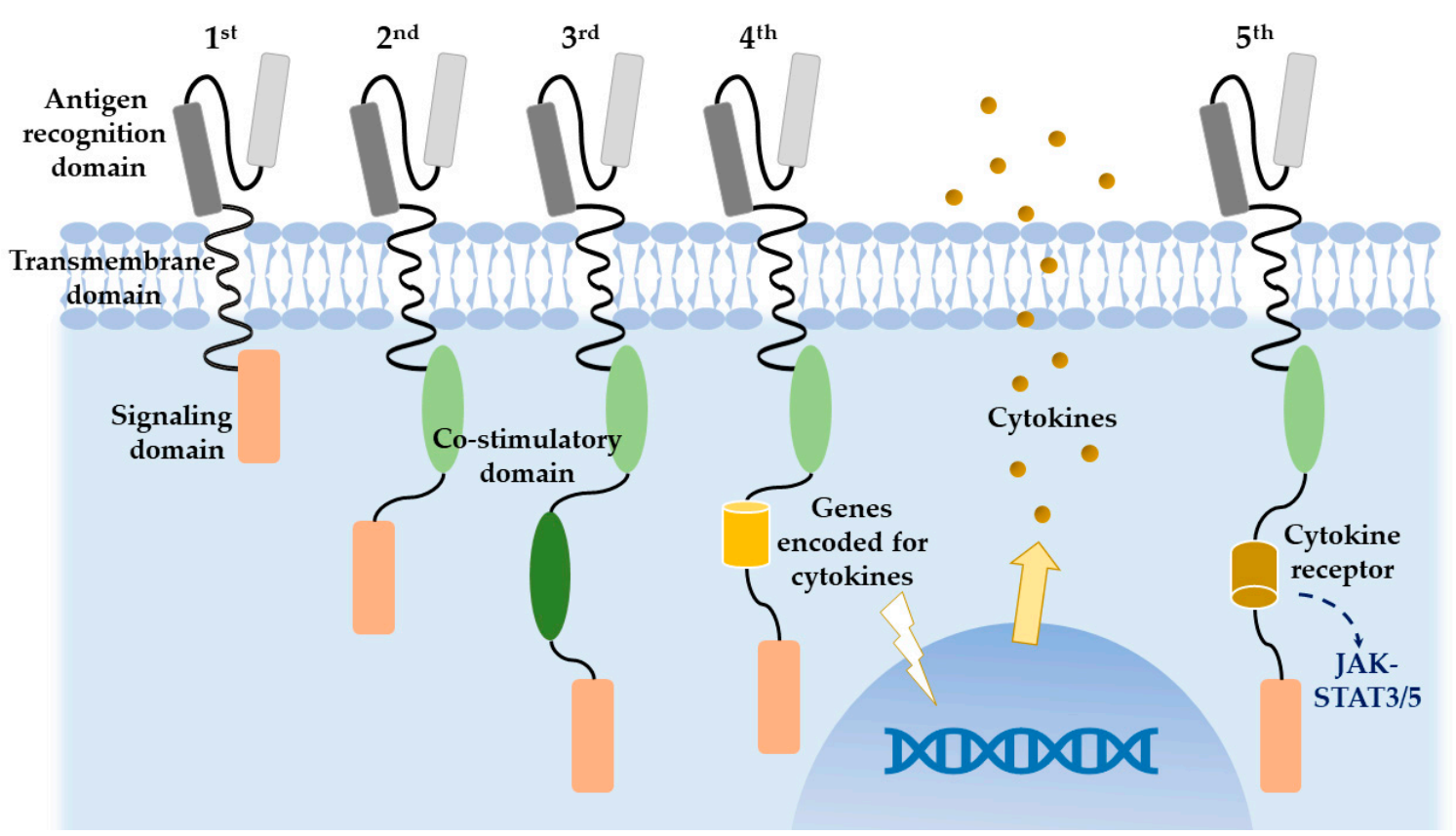

Figure 1. Structures of five generations of CAR T-cell therapy. The extracellular antigen-binding domain typically comprised of variable heavy and light chains to form a single chain variable fragment $(\mathrm{scFv})$ from a monoclonal antibody. The ectodomain is then coupled with the endo-domain through the transmembrane domain. In the first generation, the intracellular domain is typically equipped with CD3 $\zeta$ of the T-cell receptor. In the second generation, CD28 or 4-1BB is added to the intracellular domain. The modified third generation then contains both. The novel fourth generation contains genes encoded for cytokines for transgenic expression, such as IL-12 and IL18, which can further activate cytokines. The developing fifth generation comprise of IL-2 receptor $\beta$-chain domain that further promotes cytokine cassette.

\subsection{Protocol of CART-Cell Therapy}

Current regimen of CAR T-cell therapy follows a general protocol (Figure 2)-patient's T-cells are first collected, purified, and activated with antibodies or antibody-coated beads artificially. This is followed by transduction of CAR molecule into T-cell using transient transfection via lentivirus, retrovirus transduction, or electroporation [20]. The modified CAR T-cells were then multiplied in vitro to a sufficient amount before being infused back into the patient. Prior to the transfusion, the patient receives lymphodepleting chemotherapy, such as various doses of cyclophosphamide alone, fludarabine and cyclophosphamide, pentostatin and cyclophosphamide, bendamustine-based regimens, and several disease-specific regimens determined at physician's discretion. The addition of lymphodepletion chemotherapy was anecdotally shown to increase persistence of CAR T-cell therapy. No regimen was clearly shown to be superior in terms of efficacy for optimizing CAR T-cell activity, nor is it clear which particular method is more toxic than another [20]. 


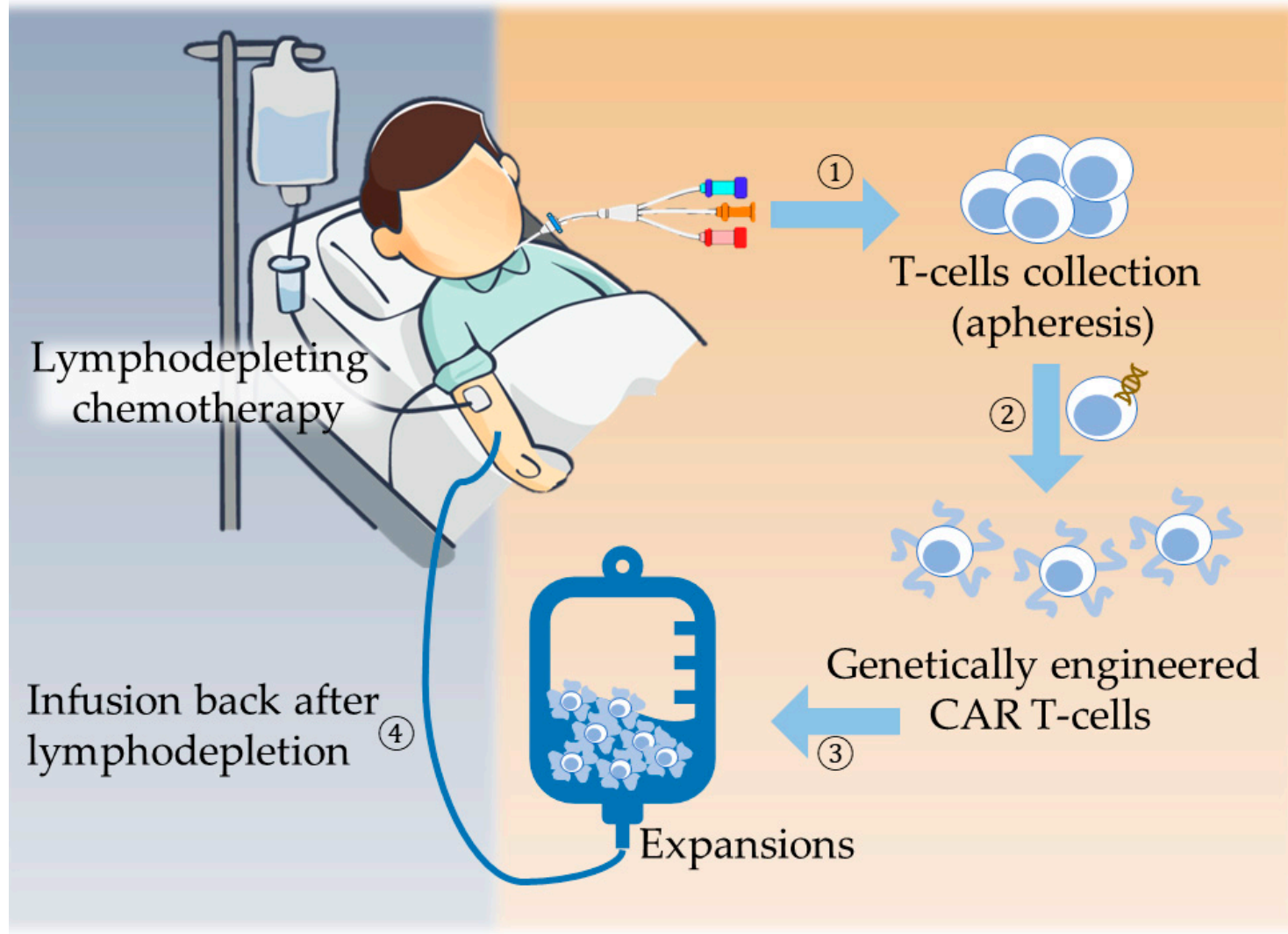

Figure 2. CAR T-cell therapy protocol: (1) T-cell collected from patient's peripheral blood. (2) Artificial antigen and costimulatory domains are engineered into T-cells. (3) Amplification of CAR T-cells to sufficient amount. (4) Infuse CAR T-cells back into patient's body after lymphodepletion.

\section{CAR T-Cell Therapy in Hematological Malignancies}

In 2017, two anti-CD19 CAR T-cell products, Tisagenlecleucel and axicabtagene ciloleucel, received FDA approval, respectively. Tisagenlecleucel was approved for multiple relapsed/refractory $(\mathrm{r} / \mathrm{r})$ pediatric acute lymphoblastic leukemia (ALL). Moreover, both tisagenlecleucel and axicabtagene ciloleucel could be used for diffusing large B-cell lymphoma (DLBCL) after two or more lines of therapy. In 2020, the FDA further granted the use of brexucabtagene autoleucel, a CD19-directed CAR T-cell therapy for adult patients with $\mathrm{r} / \mathrm{r}$ mantle cell lymphoma (MCL). Currently, multiple trials are ongoing, and a list of current antigens targeting different hematological malignancies are summarized in Table 1. The following paragraphs discuss the applications and limitations of common hematological malignancies.

Table 1. Current CAR T-cell therapy targets in hematological malignancies.

\begin{tabular}{ccc}
\hline Disease & CAR T-Cell Therapy Targets & Phase \\
\hline & CD19 [21,22] & I, II \\
CD22 [23,24] & I, I \\
I \\
Acute Lymphoblastic Leukemia & Dual CD19 and CD22 [25] & I \\
& Dual CD28 and CD137 (NCT02186860) & I \\
CD33 (NCT02799680) & I \\
& CD20/CD22/CD10 (NCT03407859) & N/A \\
& CD33/CD38/CD56/CD123/CD117/CD133/CD34/Mucl (NCT03473457) & I/II \\
CS123 (NCT03556982) & I \\
CDCAR-CD22/CD123/CD38/CD10/CD20/TSLPR (NCT04016129) & I/II \\
XYF19 (NCT04037566) & I \\
\hline
\end{tabular}


Table 1. Cont

\begin{tabular}{|c|c|c|}
\hline Disease & CAR T-Cell Therapy Targets & Phase \\
\hline Multiple Myeloma & $\begin{array}{c}\text { BCMA }^{1}[26,27] \\
\text { BCMA and/or CD19 [28] } \\
\text { CD138 (NCT01886976) } \\
\text { CD138/BCMA/CD19/more (NCT03196414) } \\
\text { BCMA/CD38/CD56/CD138/alternative antigens (NCT03271632, } \\
\text { NCT03473496) } \\
\text { CD38 (NCT03464916) } \\
\text { NY-ESO-1 (NCT03638206) } \\
\text { IM21 (NCT03711864, NCT04537442) } \\
\text { Dual BCMA and CD38 (NCT03767751) } \\
\text { Integrin } \beta 7 / \text { BCMA/CS1/CD38/CD138 (NCT03778346) } \\
\text { CD44v6 NL (NCT04097301) } \\
\text { CD4 (NCT04162340) } \\
\text { SLAMF7 (NCT04499339) } \\
\text { CS1 (NCT04541368) }\end{array}$ & $\begin{array}{c}\mathrm{Ib} / \mathrm{II}, \mathrm{I} \\
\text { I/II } \\
\text { I/II } \\
\text { I/II } \\
\text { I/II, N/A I } \\
\text { I/II } \\
\text { I, I } \\
\text { I/II } \\
\text { I } \\
\text { I/II } \\
\text { I } \\
\text { I/II } \\
\text { I }\end{array}$ \\
\hline Diffuse Large B Cell Lymphoma & $\begin{array}{c}\text { CD19 [29,30] } \\
\text { Dual CD19 and CD20/CD22 [31] }\end{array}$ & $\begin{array}{l}\text { II, II } \\
\text { In vivo }\end{array}$ \\
\hline Non-Hodgkin Lymphoma & $\begin{array}{c}\text { CD19 }[21,32,33] \\
\text { Dual CD19 and CD20 [34] } \\
\text { CD19/CD20/CD22/CD30 (NCT03196830) } \\
\text { CD20 (NCT03664635, NCT04169932) } \\
\text { Dual CD19 and CD22 (NCT04303247, NCT04412174) }\end{array}$ & $\begin{array}{l}\text { I, I, I } \\
\text { I } \\
\text { II } \\
\text { I/II, I } \\
\text { I, I }\end{array}$ \\
\hline Hodgkin Lymphoma & CD30 [35] & I \\
\hline $\begin{array}{l}\text { NK/T-Cell Lymphoma } \\
\text { T-Lymphoblastic Lymphoma }\end{array}$ & CD7 (NCT04004637, NCT04572308) & I, N/A \\
\hline $\begin{array}{l}\text { Acute Myeloid Leukemia } \\
\text { NK Cell Lymphoma } \\
\text { T-Cell Acute Lymphoblastic Leukemia }\end{array}$ & CD7 (NCT04033302) & I/II \\
\hline $\begin{array}{c}\text { Adult T-Cell Lymphoma/Leukemia } \\
\text { Anaplastic Large Cell Lymphoma } \\
\text { Angioimmunoblastic T-Cell Lymphoma } \\
\text { Hodgkin Lymphoma } \\
\text { NK/T-Cell Lymphoma } \\
\text { Peripheral T-Cell Lymphoma }\end{array}$ & CD30 (NCT04008394) & I \\
\hline $\begin{array}{l}\text { Anaplastic Large Cell Lymphoma } \\
\text { Extra-nodal NK/T-Cell Lymphoma } \\
\text { Diffuse Large B Cell Lymphoma } \\
\text { Peripheral T-Cell Lymphoma } \\
\text { Primary Mediastinal Large B-Cell Lymphoma }\end{array}$ & CD30 (NCT04526834) & I \\
\hline Lymphoma & $\begin{array}{c}\text { CD30(NCT02259556, NCT02917083) } \\
\text { 4SCAR20/22/70/PSMA/13/79b/GD2 (NCT04429438) }\end{array}$ & $\begin{array}{l}\mathrm{I} / \mathrm{II}, \mathrm{I} \\
\mathrm{I} / \mathrm{II} \\
\end{array}$ \\
\hline Chronic Lymphocytic Leukemia & CD19 (NCT03085173) & I \\
\hline Acute Myeloid Leukemia & $\begin{array}{c}\text { CD33 [36] } \\
\text { CD123 [37] } \\
\text { CLL-1+CD33 [38] } \\
\text { Muc1/CLL1/CD33/CD38/CD56/CD123 (NCT03222674) } \\
\text { CD38/CD33/CD56/CD123/CD117/CD133/CD34/Mucl (NCT03473457) } \\
\text { CD123/CLL1 (NCT03631576) } \\
\text { CLL-1/CD33 and/or CD123 (NCT04010877) } \\
\text { CD44v6 } 1 \text { NL (NCT04097301) } \\
\text { CD19 (NCT04257175) } \\
\text { CD38 (NCT04351022) }\end{array}$ & $\begin{array}{l}\text { I/II } \\
\text { I } \\
\text { I } \\
\text { N/A } \\
\text { N/A } \\
\text { I/II } \\
\text { N/A } \\
\text { II/III } \\
\text { II/III } \\
\text { I/II }\end{array}$ \\
\hline $\begin{array}{l}\text { Acute Myeloid Leukemia } \\
\text { Myelodysplastic Syndrome }\end{array}$ & $\begin{array}{c}\text { NKG2D (NCT03018405) } \\
\text { CD33/CD38/CD56/CD117/CD123/CD34/Muc1 CAR T-cells + Eps8 or } \\
\text { WT1 peptide specific dendritic cell (NCT03291444) }\end{array}$ & $\begin{array}{c}\mathrm{I} / \mathrm{II} \\
\mathrm{I}\end{array}$ \\
\hline $\begin{array}{l}\text { Acute Myeloid Leukemia } \\
\text { Myelodysplastic Syndrome } \\
\text { Myeloproliferative neoplasms }\end{array}$ & $\begin{array}{l}\text { CLL1-CD33 (NCT03795779) } \\
\text { CD123-CD33 (NCT04156256) }\end{array}$ & $\begin{array}{l}\text { I } \\
\text { I }\end{array}$ \\
\hline Chronic Myeloid Leukemia & IL-1RAP (NCT02842320) & N/A \\
\hline CD4+ T-Cell Lymphoma & LCAR-T2C (NCT04219319) & I \\
\hline
\end{tabular}

The order of the diseases listed in the table are arranged according to the order mentioned in the main text. In each disease, antigens with known publication are listed in Figure $1 .{ }^{1}$ BCMA (B cell maturation antigen). 


\section{1. r/r B-Cell Acute Lymphoblastic Leukemia}

The response to tisagenlecleucel in patients with $\mathrm{r} / \mathrm{r}$ B-cell ALL, was first well understood during a phase 1-2a study conducted at the Children's Hospital of Philadelphia and the University of Pennsylvania [39]. The study involved 60 children and young adults and yielded a complete remission rate of $93 \%$ [39]. The 4-year follow-up demonstrated significant disease control without additional therapy needed $[39,40]$. The ELIANA trial, based on these results, extended the research area to 25 study sites in 11 countries across North America, Europe, Australia, and Asia. The trial revealed 61 out of 75 (81\%) patients less than 21-years-old had remission within 3 months, and the event-free survival and overall survival were $50 \%$ and $76 \%$ at 12 months, respectively [41]. This result promoted FDA's approval for tisagenlecleucel in young adult with $\mathrm{r} / \mathrm{r}$ B-cell ALL. Recent update of the ELIANA trial in 2019, under a median follow-up of 24 months, demonstrated ongoing response in 29 patients (45\%), with a current maximum duration of 29 months [22]. Further clinical trials using CD19 CAR T-cell therapy in patients with $\mathrm{r} / \mathrm{r}$ ALL also showed remarkable results, with the complete response rate varying from $67 \%$ to $93 \%$ [41-50]. Patients' quality-of-life after tisagenlecleucel infusion at 3 months also showed dramatic improvement based on a patient-reported questionnaire [51].

However, relapse of CD19 negative clones was detected in up to $20 \%$ of patients, post-CAR T-cell therapy [39]. In this situation, CD22 CAR might play a role as anti-CD22 antibody, inotuzumab, which recently received approval for relapsed B-cell ALL [52], and CD22 CAR was reported to induce remissions in patients who were CAR T-cell therapy naïve or with relapse after anti-CD19 CAR T-cell therapy [23]. Furthermore, the studies focused on targeting more than 1 antigen, such as CD19 with either CD20 or CD22, are ongoing $[53,54]$ and might change the paradigm of the $r / r$ ALL treatment.

\section{2. $r / r$ Large B-Cell Lymphoma}

DLBCL is the most common non-Hodgkin's lymphoma [55]. Despite its noteworthy response to the classic R-CHOP regimen, namely combination of rituximab with cyclophosphamide, doxorubicin, vincristine, and prednisone, up to a $15 \%$ refractory rate within 3 months was noted and around $35 \%$ patients had a chance of relapse [56]. In patients with primary refractory DLBCL or relapse, receiving autologous transplantation only yielded a complete response rate of $7 \%$ per year and a median overall survival of 6.2 months [57], calling for the need of advanced treatments. In a phase $2 a$, single-center study, the tisagenlecleucel in patients with $\mathrm{r} / \mathrm{r}$ DLBCL, demonstrated a $50 \%$ response rate at 3 months, with $43 \%$ having a complete response at 6 months [58]. Based on this result, the JULIET trial was initiated. The update of the trial revealed that the overall response rate was $52 \%$, with $40 \%$ of the 93 patients showing complete responses, and $12 \%$ showing partial responses [30]. The median overall survival among patients who received an infusion was 12 months [30,59]. Axicabtagene-ciloleucel, another anti-CD19 CAR T-cell therapy, showed 4 out of 7 patients with complete response, and 3 remained in remission at 1 year [60]. A phase 2 trial of ZUMA-1 was then conducted and the response rate was $82 \%$, with a complete response rate of $54 \%$ [29], which later led to FDA's approval of axicabtagene-ciloleucel for $\mathrm{r} / \mathrm{r}$ DLBCL. The 2-year follow-up data involving $108 \mathrm{r} / \mathrm{r}$ LBCL patients, declared overall response rate as $82 \%$, with a $58 \%$ complete response [61]. The updated analysis by Locke and colleagues, with a median follow up of 27.1 months, still observed ongoing responses in 39\% of patients, with $37 \%$ maintaining complete response [62]. The real-world use of axicabtagen-ciloleucel across 17 academic centers in the US also reported an overall response rate of $79 \%$ with $50 \%$ complete response, consistent with the aforementioned clinical trials. These data led to three ongoing randomized phase III clinical trials in primary refractory or high-risk relapsed DLBCL (NCT03391466, NCT03575351, and NCT03570892). The control arm in each of these studies involved second-line intensive chemotherapy, followed by autologous stem cell transplant. Another CAR T-cell therapy lisocabtagene-maraleucel, also CD19-directed, is currently under investigation in late-stage clinical trials but is not yet approved by the FDA [33]. However, emerging data with high rate of relapse or progressive disease post-CAR T-cell therapy, raise concern for bridging therapy for disease stabilization prior to CAR T-cell therapy administration, as well as subsequent therapies [63]. 


\subsection{Multiple Myeloma}

Multiple myeloma (MM) accounts for $~ 10 \%$ of all hematologic malignancies in the United States, with the highest incidences observed in developed countries, and considered to be a non-curable disease with inevitable relapse [64]. In contrast to previous two B-cell malignancies, myeloma cells rarely express CD19. Identifying other targets thus disadvantages the application of CAR T-cell therapy in MM. Recently, a member of the TNF receptor superfamily, B-cell maturation antigen (BCMA), which binds to B-cell activating factor and a proliferation-inducing ligand (APRIL) [65,66], was found to express on primary human CD34+ hematopoietic cells and are commonly expressed in plasma cells and primary myeloma cells $[67,68]$. This then became the target of CAR T-cell therapy in MM [69-71]. Currently, multiple BCMA CAR T-cell products are under investigation, including the first phase III study, KarMMa-3 study (NCT03651128). These compared the bb2121 BCMA CAR T-cell product to the current standard regimen of daratumumab-containing triplet therapies, in patients previously receiving more than 2 lines of therapy. A phase II study of LCAR-B38M (NCT03758417), a phase IB/II study of JNJ-68284528, namely CARTITUDE-1 study (NCT03548207) and a phase I/II study of JCARH125 (NCT03430011) referred to as the EVOLVE study is also ongoing. The updated analysis for these trials showed ORR $>80 \%$ in patients with $\mathrm{r} / \mathrm{r} \mathrm{MM}$ [72]. However, the duration of response ranged from 4 to 16 months $[69,73]$ and the details of this study are subject to further scrutiny. The BCMA CAR T-cell therapy is awaiting approval for treatment of $\mathrm{r} / \mathrm{r} \mathrm{MM}$ with more than three prior lines of therapy. Nevertheless, earlier intervention of CAR T-cell therapy in the disease course was investigated in the KarMMa-2 phase II study (NCT03601078). Other strategies to improve persistence and efficacy of the BCMA CAR T-cell therapy included dual CAR T-cell therapy targets of both CD19 and BCMA [28,74], combination of infusion components [75,76], altered construct [77-79], and enriched culture medium $[80,81]$.

\subsection{Other $r / r$ Lymphocytic Disease}

In $\mathrm{r} / \mathrm{r}$ chronic lymphocytic leukemia, the response rate was around 50\% using CD19 CAR T-cells therapy [82,83], and the rate even lowered to $30 \%$ once the relapse happened post HST [84]. This diminished effect in CLL could be due to the expression of different phenotypes of CD4+ T-cells. Specifically, the CLL patients were found to display less "naïve" CD4+ T-cells, which is critical for CAR T-cell persistence. In addition, the naïve CD4+ T-cells of CLL patients express even more exhaustion markers [85], such as strong expression of PD-1, CD160, and CD244, and their CD8+ T-cells have low proliferative and cytotoxic capacities [86]. These intrinsic characteristics are indeed favored by previous lines of treatment (with fludarabine, in particular), but frustrate the use of CAR T-cell therapy. Further management, including improved long-term expansion and maintenance of CAR T-cell populations using Ibrutinib, which redirects the immune response of autologous T-cells from a Th2 profile to a Th1 profile will be evaluated in clinical trials (NCT03331198) [87]. The next stage of CAR T-cell therapy for lymphoblastic leukemia could be targeting the CD30 antigen for Hodgkin lymphoma (HL), and clinical trials are underway $[35,88]$.

\subsection{R/r Myeloid Leukemia}

The main obstacle of application of CAR T-cell therapy to myeloid malignancies lies in the lack of unique target antigens that is distinct in malignant cells from healthy progenitor cells. For a long time, a number of target antigens were proposed, including CD123 [89,90], LeY antigen [91], folate receptor- $\beta$ [92], and CD33 [93], based on preclinical studies. Other antigens like FLT3, CD7, ADGRE2, CCR1, CD70, and LILRB2 are summarized in Cummins and Gill's work [94]. Sporadic case reports are congruous with the promising data of CD123- and CD33-directed CAR T-cell therapy in pre-clinical models [93,95,96], with more than 20 clinical trials ongoing [97], and we listed all phase II/III CAR T-cell trials containing adult $r / r$ acute myeloid leukemia (AML) in Table 2. To avoid the off-target killing of normal hematopoietic cells, limited CAR T-cell persistence, in contrast to B-cell 
malignancies, might circumvent neutropenic infections and bleeding complications [97]. Multiple studies on controlling CAR T-cell persistence were carried out, including engineering a suicide gene in CAR T-cell, such as herpes simplex virus-thymidine kinase (HSV-tk) [98] or inducible caspase 9 (iCasp9) [99,100]. These co-expressed a well-characterized surface antigen, whose monoclonal antibodies are available [101,102], or used a less persistence costimulatory domain of CD28 rather than high persistent 4-1BB [103]. In addition, blasts in AML, actually hampered the production of CAR T-cell [104], with only $1 / 3$ patients showing sufficient numbers for further manufacture in a small phase I study involving CD123 CAR T-cell [105]. This would need further manifestations in engineering CAR T-cell. 
Table 2. Current CAR T-cell phase II/III clinical trials including adult relapsed/refractory acute myeloid leukemia.

\begin{tabular}{|c|c|c|c|c|c|}
\hline Clinical Trial and Institution & Target & Phase & $\mathbf{N}$ & Age & Lymphodepleting Chemotherapy \\
\hline $\begin{array}{c}\text { NCT04033302 } \\
\text { Shenzhen Geno-Immune Medical Institute }\end{array}$ & CD7 & $1 \& 2$ & 30 & 6 Months to 75 Years & Not mentioned \\
\hline $\begin{array}{l}\text { NCT02742727 } \\
\text { PersonGen BioTherapeutics (Suzhou) Co., Ltd. }\end{array}$ & CD7 & $1 \& 2$ & 10 & 18 Years and older & Not mentioned \\
\hline $\begin{array}{c}\text { NCT04257175 } \\
\text { Sheba Medical Center }\end{array}$ & CD19 & $2 \& 3$ & 10 & 18 Years and older & cyclophosphamide and fludarabine \\
\hline $\begin{array}{l}\text { NCT03896854 } \\
\text { Shanghai Unicar-Therapy Bio-medicine Technology Co., Ltd. } \\
\text { NCT03971799 }\end{array}$ & CD19 & $1 \& 2$ & 15 & 6 Years to 65 Years & Not mentioned \\
\hline $\begin{array}{c}\text { Center for International Blood and Marrow Transplant } \\
\text { Research }\end{array}$ & CD33 & $1 \& 2$ & 34 & 1 Year to 35 Years & cyclophosphamide and fludarabine \\
\hline $\begin{array}{c}\text { NCT01864902 } \\
\text { Chinese PLA General Hospital }\end{array}$ & CD33 & $1 \& 2$ & 10 & 5 Years to 90 Years & Not mentioned \\
\hline $\begin{array}{l}\text { NCT04351022 } \\
\text { The First Affiliated Hospital of Soochow University }\end{array}$ & CD38 & $1 \& 2$ & 20 & 6 Years to 65 Years & Not mentioned \\
\hline $\begin{array}{l}\text { NCT04097301 } \\
\text { MolMed S.p.A. } \\
\text { NCT03556982 }\end{array}$ & CD44v6 & $1 \& 2$ & 58 & 1 Year to 75 Years & cyclophosphamide and fludarabine \\
\hline $\begin{array}{c}\text { The Affiliated Hospital of the Chinese Academy of Military } \\
\text { Medical Sciences }\end{array}$ & CD123 & $1 \& 2$ & 10 & 14 Years to 75 Years & Not mentioned \\
\hline $\begin{array}{c}\text { NCT04272125 } \\
\text { Chongqing Precision Biotech Co., Ltd. }\end{array}$ & CD123 & $1 \& 2$ & 40 & 3 Years to 75 Years & Not mentioned \\
\hline $\begin{array}{l}\text { NCT04265963 } \\
\text { Chongqing Precision Biotech Co., Ltd. }\end{array}$ & CD123 & $1 \& 2$ & 45 & 2 Years to 75 Years & Not mentioned \\
\hline $\begin{array}{l}\text { NCT04109482 } \\
\text { Mustang Bio }\end{array}$ & CD123 & $1 \& 2$ & 126 & 18 Years and older & $\begin{array}{l}\text { Cyclophosphamide, fludarabine } \\
\text { and decitabine }\end{array}$ \\
\hline $\begin{array}{c}\text { NCT03631576 } \\
\text { Fujian Medical University }\end{array}$ & CD123/CLL1 & $2 \& 3$ & 20 & up to 70 Years & Not mentioned \\
\hline $\begin{array}{c}\text { NCT04010877 } \\
\text { Shenzhen Geno-Immune Medical Institute }\end{array}$ & CD33, CD123/CLL-1 & $1 \& 2$ & 10 & 6 Months to 75 Years & Not mentioned \\
\hline $\begin{array}{c}\text { NCT03222674 } \\
\text { Shenzhen Geno-Immune Medical Institute }\end{array}$ & Muc1/CLL1/CD33/CD38/CD56/CD123 & $1 \& 2$ & 10 & 2 Years to 75 Years & Not mentioned \\
\hline
\end{tabular}

The table enlightening current CAR T-cell phase II/III clinical trials targeting relapsed/refractory acute myeloid leukemia in adults, arranged according to the CAR T-cell target, from a small to a large number. 


\section{The Toxicity and Limitation of CAR T-Cell Therapy}

\subsection{Toxicity}

Although CAR T-cell therapy represents a relatively new era of treatment, its two major adverse effects, namely cytokine release syndrome (CRS) and neurotoxicity were reconcilable along trials $[106,107]$, which could be severe or fatal, if unrecognized. Here, we highlight the significance of close monitoring and early appropriate interventions.

\subsubsection{CRS}

Despite the life-saving result of CAR T-cell in clinical trials, its severe toxicities could also be life-threatening [108]. The most widespread severe toxicity, CRS, emanated from inflammatory interaction between CAR T-cells and tumoral B-cells. Once they were activated and expanded, cytokines, mainly IFN- $\gamma$ and TNF- $\alpha$, were released from cell lysis. Moreover, the tumoricidal activity of monocytes and macrophages were magnified and emancipated high levels of pro-inflammatory cytokines, including IL-6, IL-1, and IL-10 [109-111]. Symptoms of CRS ranged from high fevers, refractory hypotension, tachycardia, hypoxia, consumptive coagulopathy, and multiple end-organ failure [111,112]. One out of four patients present severe CRS $[110,111]$. It was reported that B-ALL had as high as $29.3 \%$ server CRS, compared to those with B-lymphoma (19.8\%) [113]. Risk factors could be derived from three main aspects-patient-related factors such as infection or inflammatory state, as well as hematopoietic cell transplantation-comorbidity index (HCT-CI), tumor-related factors, including disease type and tumor burden, and CAR T-cell related factors, that is CAR T-cell design and product expansion number. In addition, conditioning chemotherapy containing fludarabine was associated with the development of severe CRS [113]. Recent American Society for transplantation and cellular therapy has consensus on grading CRS according to body temperature, hypotension requiring a vasopressor or not, and oxygen demand from grade 1 to 4 [114,115]. Management of toxicity was based on its clinical presentations, and tocilizumab, an anti-interleukin (IL)-6 receptor antibody, was suggested once toxicity reached grade 2 or higher [114].

\subsubsection{Neurotoxicity}

Neurotoxicity is the second most common toxicity in CAR T-cell therapy, also referred to as immune effector cell-associated neurotoxicity syndrome (ICANS) or CAR T-cell-related encephalopathy syndrome (CRES). It contains diverse symptoms that are not limited to one region of body, such as headache, delirium, hallucinations, cognitive defects, expressive aphasia, apraxia, somnolence, tremors, ataxia, nerve palsies, focal motor or sensory deficits, myoclonus, etc. It can also progress to severe encephalopathy, including seizures, obtundation, and even cerebral edema, which leads to death [116]. It was proposed that there are two patterns of neurotoxicity [108]. One might correspond to breakdown of the blood-brain barrier through cytokine production of IL-1, IL-6, and TNF- $\alpha$, which occur immediately after CRS and affect angiotensin $1 / 2$ balance, bringing stress to brain vascular pericyte and enhancing endothelium-activating cytokines [117]. The other pattern is linked to the expansion and activation of CAR T-cells, which lead to a direct parenchymal CAR T-cell infiltration into central nervous system, where pan-T encephalitis was demonstrated in an animal model [118]. This finding correlates with the finding that higher serum level of inflammatory markers such as CRP, early peak of IL-6, IL-2, sIL-2R $\alpha$, IL-6, IL-8, IL-10, IL-15, INF- $\gamma$, TNF- $\alpha$, granzyme B, soluble GM-CSF, and MCP-1 [106], as well as elevated protein and multiple cytokines in the cerebrospinal fluid (CSF), accompany severe neurological toxicity $[119,120]$. Although there is no clear link between the costimulatory domain and neurological toxicity, anti-CD22 CAR T-cell for ALL exhibited a favorable neurotoxicity profile compared to that of anti-CD19 [23], and anti-BCMA displayed less frequent severe neurological toxicity $[69,121]$. Further clinical trials containing a larger number of samples are needed to define the correlation. While the pathogenesis of neurological toxicity remains unclear, its toxicity grade was observed to be associated with higher grade CRS [41,112,119], revealing overlapping risk factors with 
CRS, despite independent mechanisms. The severity could be graded using Common Terminology Criteria for Adverse Events (CTCAE) system, which was widely used across many centers [106]. The CAR-T-cell therapy-associated (CARTOX) consensus group also published a grading system for CAR T-cell neurological toxicity, which mainly focuses on cognitive functions, except that seizures, motor weakness, or papilledema directly result in grade of 3 or higher [111]. The Pediatric Oncology Group at the NCI and colleagues developed their own grading system combining patients' cognitive test and observer-reported checklist [122]. The recent ASTCT consensus grading system then highlights the immune effector cell-associated encephalopathy scores, seizures, motor weakness, and raised intracranial pressure or cerebral edema as a new index [114]. It is suggested to closely monitor neurological toxicity throughout the treatment and exclude other possible factors like infection or electrolyte imbalance, which leads to neurotoxicity. Levetiracetam $500 \mathrm{mg}$ twice daily for seizure prophylaxis is also recommended to use in patient with grade 1-2 neurotoxicity and steroid in grade 2-3 [114].

\subsection{Limitations}

CAR T-cell therapy, which replaces "drug" with "cell", encompasses several advantages as well as disadvantages. Its advantages in hematological malignancies include constant contact of CAR T-cell with malignant cells. Additionally, patients could be easily followed up through peripheral blood draw. The ceaseless contiguity is indeed one of its disadvantages, as the inflammatory response and cytokine milieu might also stimulate malignant cells. Additionally, as malignant cells originate from normal immune system and hemopoietic cells, in patients receiving CAR T-cell, it would display server deficient immune system and neutropenia, which are susceptible to infections [123]. Importantly, the close exposure might lead to easy immune evasion, thus reducing CAR T-cell potency [124]. Finally, as CAR T-cell is a highly personalized medicine, its cost is still high and did not yet reach general commercial production. Additionally, as CAR T-cell therapy is currently used in $\mathrm{r} / \mathrm{r}$ disease, the prior treatments and conditioning therapies differs, further effort is needed to reach a consensus.

\subsection{Challenges}

The pioneering work in CAR T-cell therapy is altering the treatment for patients with $\mathrm{r} / \mathrm{r}$ hematological malignancies. However, despite the current remarkable results, many challenges remain in this field. First, post-CAR T-cell relapse was reported and is becoming more of a concern as CAR T-cell therapy is more widely used. There are two main patterns of post-CAR T-cell relapse-one is evading CAR-mediated recognition and clearance because of the lack of targeting antigen, whereas the other is the lack of CAR T-cell persistence [125]. The former could be overcome by using a combination of either another CAR T-cell, or another monoclonal antibody. Indeed, CD22 CAR T-cell was used in post-CD19 CAR T-cell relapse [23], and a dual CAR T-cell, which targeted both CD19 and CD20 or CD22 was proposed [31]. Other monoclonal antibodies, such as rituximab and inotuzumab, could both be combined with non-CD20 or non-CD22 CAR T-cell therapy to widen targets range.

The later could also be improved on multiple aspects. First, by modifying the CAR structure, such as replacing murine $\mathrm{scFv}$ with humanized $\mathrm{scFv}$, and using a 4-1BB costimulatory molecule instead of CD28 [125]. CAR gene editing using CRISPR/Cas9 technology to "knock-in" a designated gene locus [126] as well as "knocking-out" inhibitory receptors, such as LAG-3, TIM-3, and CTLA-4 [127] (which were found to be highly expressed when T-cells are exhausted from chronic activation [128,129]) or CD3, HLA-I, Fas triple-ablated CAR T-cells in vitro and in vivo, also ameliorate CAR T-cell efficacy by enhancing the anti-tumor activity of T-cells [130]. Designing artificial antigen-presenting cells that could activate CAR T-cells by releasing IL-21 and IL-15 was also able to stimulate and amplify the number of CAR T-cells $[131,132]$. The use of checkpoint inhibitors, such as nivolumab, atezolizumab, or durvalumab [133-135], by regulating the programmed death ligand 1/programmed cell death 1 (PD-L1/PD-1) axis, also enhanced the anti-tumor activity of T-cells [136] to modify tumor microenvironment [137]. Other "consolidation" therapy, such as Lenalidomide (NCT03070327) [138], 
cereblon-modulating agent CC-122 (NCT03310619), celecoxib, and histone deacetylase inhibitors as possible modalities [139], are under investigations. In addition, whether it is advisable to receive hematopoietic cell transplant (HCT) following CAR T-cell therapy, is still under debate [140]. Recent report indicates that HCT appears to benefit subjects that attain a complete response but are at an increased risk of relapse [141].

The second issue would be to generate "off-the-shelf" immunotherapy in the hopes of reducing the risk of graft-versus-host disease. Recently, Boissel et al. [142] successfully produced CD19-CAR NK cells from the NK-92 cell line, with cytolytic function against resistant chronic lymphoblastic leukemia cells [143]. Efficient CD19-CAR NK cells against B cell leukemia [144-146] and myeloma [147] were also reported. "Armored CAR", possessing the ability to secrete cytokines like IL-18, which constitutively express CD40L to enhance IL-12 secretion or constitutively express 4-IBB ligand to modulate the tumor microenvironment, are also being examined [148,149]. Additionally, targeting extracellular matrix or T-lymphocyte exclusion pathways, e.g., VEGF or TGF $\beta$, which are future avenues for applications of CAR T-cell in solid tumors, might in turn provide a possible method to modify the tumor microenvironment in hematological malignancies [150].

In addition to the basic science, a couple of issues regarding CAR T-cell therapy applied in current practice should be taken into considerations as well. As the aforementioned CAR T-cell trials were all employed in $\mathrm{r} / \mathrm{r}$ hematological malignancies, it would be of great interest to study if earlier applications of CAR T-cell therapy would benefit the outcome, which, in particular, would change the treatment paradigm of hematological cancer. In addition, the initial CAR T-cell therapy got striking success in young adults, whereas most hematological malignancies, such as myeloma, were diagnosed in people older than 60 years old. In the elderly, the frailty of the patient should be taken into considerations [151], and might need close surveillances. Finally, as CAR T-cell therapy endures highly personalized medicine, questions about dosing, timing, and duration of response requires well-designed clinical trials to answer. At this point, current data are too trivial to reach a conclusion, but expanding experiences outside of single centers is growing. From the financial point of view, a structured manufacturing process should be reached to lower the cost, and quality of production should be regulated as more and more companies step into the field [152,153]. With the understanding of the molecular and physiology of this therapy, and strong cooperation between the laboratory and the clinic, CAR T-cells are anticipated to be used in an increasing number of patients with hematological malignancies and would shape the future of this field dramatically.

Funding: This research was funded by Taipei Veterans General Hospital, grant number V108B-032.

Conflicts of Interest: The authors declare no conflict of interest.

\section{References}

1. Coller, B.S. Blood at 70: Its roots in the history of hematology and its birth. Blood 2015, 126, 2548-2560. [CrossRef] [PubMed]

2. Cirillo, M.; Tan, P.; Sturm, M.; Cole, C. Cellular Immunotherapy for Hematologic Malignancies: Beyond Bone Marrow Transplantation. Biol. Blood Marrow Transplant. 2018, 24, 433-442. [CrossRef] [PubMed]

3. Im, A.; Pavletic, S.Z. Immunotherapy in hematologic malignancies: Past, present, and future. J. Hematol. Oncol. 2017, 10, 94. [CrossRef] [PubMed]

4. Sadelain, M.; Brentjens, R.; Rivière, I. The basic principles of chimeric antigen receptor design. Cancer Discov. 2013, 3, 388-398. [CrossRef]

5. Srivastava, S.; Riddell, S.R. Engineering CAR-T cells: Design concepts. Trends Immunol. 2015, 36, 494-502. [CrossRef]

6. Hombach, A.; Wieczarkowiecz, A.; Marquardt, T.; Heuser, C.; Usai, L.; Pohl, C.; Seliger, B.; Abken, H. Tumor-specific $\mathrm{T}$ cell activation by recombinant immunoreceptors: $\mathrm{CD} 3$ zeta signaling and CD28 costimulation are simultaneously required for efficient IL-2 secretion and can be integrated into one combined CD28/CD3 zeta signaling receptor molecule. J. Immunol. 2001, 167, 6123-6131. [CrossRef] 
7. Lafferty, K.J.; Cunningham, A.J. A new analysis of allogeneic interactions. Aust. J. Exp. Biol. Med. Sci. 1975, 53, 27-42. [CrossRef]

8. Brentjens, R.J.; Latouche, J.B.; Santos, E.; Marti, F.; Gong, M.C.; Lyddane, C.; King, P.D.; Larson, S.; Weiss, M.; Rivière, I.; et al. Eradication of systemic B-cell tumors by genetically targeted human T lymphocytes co-stimulated by CD80 and interleukin-15. Nat. Med. 2003, 9, 279-286. [CrossRef]

9. Pule, M.A.; Savoldo, B.; Myers, G.D.; Rossig, C.; Russell, H.V.; Dotti, G.; Huls, M.H.; Liu, E.; Gee, A.P.; Mei, Z.; et al. Virus-specific $\mathrm{T}$ cells engineered to coexpress tumor-specific receptors: Persistence and antitumor activity in individuals with neuroblastoma. Nat. Med. 2008, 14, 1264-1270. [CrossRef]

10. Till, B.G.; Jensen, M.C.; Wang, J.; Chen, E.Y.; Wood, B.L.; Greisman, H.A.; Qian, X.; James, S.E.; Raubitschek, A.; Forman, S.J.; et al. Adoptive immunotherapy for indolent non-Hodgkin lymphoma and mantle cell lymphoma using genetically modified autologous CD20-specific T cells. Blood 2008, 112, 2261-2271. [CrossRef]

11. Finney, H.M.; Lawson, A.D.; Bebbington, C.R.; Weir, A.N. Chimeric receptors providing both primary and costimulatory signaling in T cells from a single gene product. J. Immunol. 1998, 161, 2791-2797. [PubMed]

12. Brentjens, R.J.; Santos, E.; Nikhamin, Y.; Yeh, R.; Matsushita, M.; La Perle, K.; Quintás-Cardama, A.; Larson, S.M.; Sadelain, M. Genetically targeted T cells eradicate systemic acute lymphoblastic leukemia xenografts. Clin. Cancer. Res. 2007, 13, 5426-5435. [CrossRef] [PubMed]

13. Imai, C.; Mihara, K.; Andreansky, M.; Nicholson, I.C.; Pui, C.H.; Geiger, T.L.; Campana, D. Chimeric receptors with 4-1BB signaling capacity provoke potent cytotoxicity against acute lymphoblastic leukemia. Leukemia 2004, 18, 676-684. [CrossRef] [PubMed]

14. Zhang, C.; Liu, J.; Zhong, J.F.; Zhang, X. Engineering CAR-T cells. Biomark. Res. 2017, 5, 22. [CrossRef]

15. Morgan, R.A.; Yang, J.C.; Kitano, M.; Dudley, M.E.; Laurencot, C.M.; Rosenberg, S.A. Case report of a serious adverse event following the administration of $\mathrm{T}$ cells transduced with a chimeric antigen receptor recognizing ERBB2. Mol. Ther. 2010, 18, 843-851. [CrossRef]

16. Heczey, A.; Louis, C.U.; Savoldo, B.; Dakhova, O.; Durett, A.; Grilley, B.; Liu, H.; Wu, M.F.; Mei, Z.; Gee, A.; et al. CAR T Cells Administered in Combination with Lymphodepletion and PD-1 Inhibition to Patients with Neuroblastoma. Mol. Ther. 2017, 25, 2214-2224. [CrossRef]

17. Chmielewski, M.; Abken, H. TRUCKs: The fourth generation of CARs. Expert Opin. Biol. Ther. 2015, 15, 1145-1154. [CrossRef]

18. Chmielewski, M.; Abken, H. TRUCKS, the fourth-generation CAR T cells: Current developments and clinical translation. Adv. Cell Gene Ther. 2020, 3, e84. [CrossRef]

19. Tokarew, N.; Ogonek, J.; Endres, S.; von Bergwelt-Baildon, M.; Kobold, S. Teaching an old dog new tricks: Next-generation CAR T cells. Br. J. Cancer 2019, 120, 26-37. [CrossRef]

20. Holstein, S.A.; Lunning, M.A. CAR T-Cell Therapy in Hematologic Malignancies: A Voyage in Progress. Clin. Pharmacol. Ther. 2020, 107, 112-122. [CrossRef]

21. Gauthier, J.; Hirayama, A.V.; Hay, K.A.; Sheih, A.; Pender, B.S.; Hawkins, R.M.; Vakil, A.; Phi, T.-D.; Steinmetz, R.N.; Chapuis, A.G.; et al. Immunotherapy with T-Cells Engineered with a Chimeric Antigen Receptor Bearing a Human CD19-Binding Single Chain Variable Fragment for Relapsed or Refractory Acute Lymphoblastic Leukemia and B-Cell Non-Hodgkin Lymphoma. Blood 2018, 132, 1415. [CrossRef]

22. Grupp, S.A.; Maude, S.L.; Rives, S.; Baruchel, A.; Boyer, M.W.; Bittencourt, H.; Bader, P.; Büchner, J.; Laetsch, T.W.; Stefanski, H.; et al. Updated Analysis of the Efficacy and Safety of Tisagenlecleucel in Pediatric and Young Adult Patients with Relapsed/Refractory (r/r) Acute Lymphoblastic Leukemia. Blood 2018, 132, 895. [CrossRef]

23. Fry, T.J.; Shah, N.N.; Orentas, R.J.; Stetler-Stevenson, M.; Yuan, C.M.; Ramakrishna, S.; Wolters, P.; Martin, S.; Delbrook, C.; Yates, B.; et al. CD22-targeted CAR T cells induce remission in B-ALL that is naive or resistant to CD19-targeted CAR immunotherapy. Nat. Med. 2018, 24, 20-28. [CrossRef] [PubMed]

24. Pan, J.; Niu, Q.; Deng, B.; Liu, S.; Wu, T.; Gao, Z.; Liu, Z.; Zhang, Y.; Qu, X.; Zhang, Y.; et al. CD22 CAR T-cell therapy in refractory or relapsed B acute lymphoblastic leukemia. Leukemia 2019, 33, 2854-2866. [CrossRef] [PubMed]

25. Amrolia, P.J.; Wynn, R.; Hough, R.E.; Vora, A.; Bonney, D.; Veys, P.; Chiesa, R.; Rao, K.; Clark, L.; Al-Hajj, M.; et al. Phase I Study of AUTO3, a Bicistronic Chimeric Antigen Receptor (CAR) T-Cell Therapy Targeting CD19 and CD22, in Pediatric Patients with Relapsed/Refractory B-Cell Acute Lymphoblastic Leukemia (r/r B-ALL): Amelia Study. Blood 2019, 134, 2620. [CrossRef] 
26. Madduri, D.; Usmani, S.Z.; Jagannath, S.; Singh, I.; Zudaire, E.; Yeh, T.-M.; Allred, A.J.; Banerjee, A.; Goldberg, J.D.; Schecter, J.M.; et al. Results from CARTITUDE-1: A Phase 1b/2 Study of JNJ-4528, a CAR-T Cell Therapy Directed Against B-Cell Maturation Antigen (BCMA), in Patients with Relapsed and/or Refractory Multiple Myeloma (R/R MM). Blood 2019, 134, 577. [CrossRef]

27. Zhao, W.-H.; Liu, J.; Wang, B.-Y.; Chen, Y.-X.; Cao, X.-M.; Yang, Y.; Zhang, Y.-L.; Wang, F.-X.; Zhang, P.-Y.; Lei, B.; et al. A phase 1, open-label study of LCAR-B38M, a chimeric antigen receptor $\mathrm{T}$ cell therapy directed against B cell maturation antigen, in patients with relapsed or refractory multiple myeloma. J. Hematol. Oncol. 2018, 11, 141. [CrossRef]

28. Yan, L.; Shang, J.; Kang, L.; Shi, X.; Zhou, J.; Jin, S.; Yao, W.; Yao, Y.; Chen, G.; Zhu, Z.; et al. Combined Infusion of CD19 and Bcma-Specific Chimeric Antigen Receptor T Cells for RRMM: Initial Safety and Efficacy Report from a Clinical Pilot Study. Blood 2017, 130, 506. [CrossRef]

29. Neelapu, S.S.; Locke, F.L.; Bartlett, N.L.; Lekakis, L.J.; Miklos, D.B.; Jacobson, C.A.; Braunschweig, I.; Oluwole, O.O.; Siddiqi, T.; Lin, Y.; et al. Axicabtagene Ciloleucel CAR T-Cell Therapy in Refractory Large B-Cell Lymphoma. N. Engl. J. Med. 2017, 377, 2531-2544. [CrossRef]

30. Schuster, S.J.; Bishop, M.R.; Tam, C.S.; Waller, E.K.; Borchmann, P.; McGuirk, J.P.; Jäger, U.; Jaglowski, S.; Andreadis, C.; Westin, J.R.; et al. Tisagenlecleucel in Adult Relapsed or Refractory Diffuse Large B-Cell Lymphoma. N. Engl. J. Med. 2019, 380, 45-56. [CrossRef]

31. Zah, E.; Lin, M.Y.; Silva-Benedict, A.; Jensen, M.C.; Chen, Y.Y. T Cells Expressing CD19/CD20 Bispecific Chimeric Antigen Receptors Prevent Antigen Escape by Malignant B Cells. Cancer Immunol. Res. 2016, 4, 498-508. [CrossRef] [PubMed]

32. Ying, Z.; Long, L.; Liu, H.; Song, Y.; Rizzieri, D.; Nejadnik, B.; Zhu, J.; Liu, C. ET190L1-ArtemisTM T Cell Therapy Results in Durable Disease Remissions with No Cytokine Release Syndrome or Neurotoxicity in Patients with Relapsed and Refractory B-Cell Lymphoma. Blood 2018, 132, 1689. [CrossRef]

33. Abramson, J.S.; Gordon, L.I.; Palomba, M.L.; Lunning, M.A.; Arnason, J.E.; Forero-Torres, A.; Wang, M.; Maloney, D.G.; Sehgal, A.; Andreadis, C.; et al. Updated safety and long term clinical outcomes in TRANSCEND NHL 001, pivotal trial of lisocabtagene maraleucel (JCAR017) in R/R aggressive NHL. J. Clin. Oncol. 2018, 36, 7505. [CrossRef]

34. Shah, N.N.; Zhu, F.; Taylor, C.; Schneider, D.; Krueger, W.; Worden, A.; Yim, S.; Fenske, T.S.; Hamadani, M.; Johnson, B.; et al. A Phase 1 Study with Point-of-Care Manufacturing of Dual Targeted, Tandem Anti-CD19, Anti-CD20 Chimeric Antigen Receptor Modified T (CAR-T) Cells for Relapsed, Refractory, Non-Hodgkin Lymphoma. Blood 2018, 132, 4193. [CrossRef]

35. Wang, C.M.; Wu, Z.Q.; Wang, Y.; Guo, Y.L.; Dai, H.R.; Wang, X.H.; Li, X.; Zhang, Y.J.; Zhang, W.Y.; Chen, M.X.; et al. Autologous T Cells Expressing CD30 Chimeric Antigen Receptors for Relapsed or Refractory Hodgkin Lymphoma: An Open-Label Phase I Trial. Clin. Cancer. Res. 2017, 23, 1156-1166. [CrossRef] [PubMed]

36. Wang, Q.S.; Wang, Y.; Lv, H.Y.; Han, Q.W.; Fan, H.; Guo, B.; Wang, L.L.; Han, W.D. Treatment of CD33-directed chimeric antigen receptor-modified $\mathrm{T}$ cells in one patient with relapsed and refractory acute myeloid leukemia. Mol. Ther. 2015, 23, 184-191. [CrossRef]

37. Budde, L.; Song, J.Y.; Kim, Y.; Blanchard, S.; Wagner, J.; Stein, A.S.; Weng, L.; Del Real, M.; Hernandez, R.; Marcucci, E.; et al. Remissions of Acute Myeloid Leukemia and Blastic Plasmacytoid Dendritic Cell Neoplasm Following Treatment with CD123-Specific CAR T Cells: A First-in-Human Clinical Trial. Blood 2017, 130, 811. [CrossRef]

38. Liu, F.; Cao, Y.; Pinz, K.; Ma, Y.; Wada, M.; Chen, K.; Ma, G.; Shen, J.; Tse, C.O.; Su, Y.; et al. First-in-Human CLL1-CD33 Compound CAR T Cell Therapy Induces Complete Remission in Patients with Refractory Acute Myeloid Leukemia: Update on Phase 1 Clinical Trial. Blood 2018, 132, 901. [CrossRef]

39. Maude, S.L.; Teachey, D.T.; Rheingold, S.R.; Shaw, P.A.; Aplenc, R.; Barrett, D.M.; Barker, C.S.; Callahan, C.; Frey, N.V.; Nazimuddin, F.; et al. Sustained remissions with CD19-specific chimeric antigen receptor (CAR)-modified T cells in children with relapsed/refractory ALL. J. Clin. Oncol. 2016, 34, 3011. [CrossRef]

40. Grupp, S.A.; Maude, S.L.; Shaw, P.A.; Aplenc, R.; Barrett, D.M.; Callahan, C.; Lacey, S.F.; Levine, B.L.; Melenhorst, J.J.; Motley, L.; et al. Durable Remissions in Children with Relapsed/Refractory ALL Treated with T Cells Engineered with a CD19-Targeted Chimeric Antigen Receptor (CTL019). Blood 2015, 126, 681. [CrossRef] 
41. Maude, S.L.; Laetsch, T.W.; Buechner, J.; Rives, S.; Boyer, M.; Bittencourt, H.; Bader, P.; Verneris, M.R.; Stefanski, H.E.; Myers, G.D.; et al. Tisagenlecleucel in Children and Young Adults with B-Cell Lymphoblastic Leukemia. N. Engl. J. Med. 2018, 378, 439-448. [CrossRef] [PubMed]

42. Lee, D.W.; Kochenderfer, J.N.; Stetler-Stevenson, M.; Cui, Y.K.; Delbrook, C.; Feldman, S.A.; Fry, T.J.; Orentas, R.; Sabatino, M.; Shah, N.N.; et al. T cells expressing CD19 chimeric antigen receptors for acute lymphoblastic leukaemia in children and young adults: A phase 1 dose-escalation trial. Lancet 2015, 385, 517-528. [CrossRef]

43. Brentjens, R.J.; Davila, M.L.; Riviere, I.; Park, J.; Wang, X.; Cowell, L.G.; Bartido, S.; Stefanski, J.; Taylor, C.; Olszewska, M.; et al. CD19-targeted T cells rapidly induce molecular remissions in adults with chemotherapy-refractory acute lymphoblastic leukemia. Sci. Transl. Med. 2013, 5, 177ra38. [CrossRef] [PubMed]

44. Davila, M.L.; Riviere, I.; Wang, X.; Bartido, S.; Park, J.; Curran, K.; Chung, S.S.; Stefanski, J.; Borquez-Ojeda, O.; Olszewska, M.; et al. Efficacy and toxicity management of 19-28z CAR T cell therapy in B cell acute lymphoblastic leukemia. Sci. Transl. Med. 2014, 6, 224ra25. [CrossRef] [PubMed]

45. Grupp, S.A.; Kalos, M.; Barrett, D.; Aplenc, R.; Porter, D.L.; Rheingold, S.R.; Teachey, D.T.; Chew, A.; Hauck, B.; Wright, J.F.; et al. Chimeric antigen receptor-modified T cells for acute lymphoid leukemia. N. Engl. J. Med. 2013, 368, 1509-1518. [CrossRef] [PubMed]

46. Saito, S.; Nakazawa, Y.; Sueki, A.; Matsuda, K.; Tanaka, M.; Yanagisawa, R.; Maeda, Y.; Sato, Y.; Okabe, S.; Inukai, T.; et al. Anti-leukemic potency of piggyBac-mediated CD19-specific T cells against refractory Philadelphia chromosome-positive acute lymphoblastic leukemia. Cytotherapy 2014, 16, 1257-1269. [CrossRef] [PubMed]

47. Maude, S.L.; Teachey, D.T.; Porter, D.L.; Grupp, S.A. CD19-targeted chimeric antigen receptor T-cell therapy for acute lymphoblastic leukemia. Blood 2015, 125, 4017-4023. [CrossRef] [PubMed]

48. Park, J.H.; Rivière, I.; Gonen, M.; Wang, X.; Sénéchal, B.; Curran, K.J.; Sauter, C.; Wang, Y.; Santomasso, B.; Mead, E.; et al. Long-Term Follow-up of CD19 CAR Therapy in Acute Lymphoblastic Leukemia. N. Engl. J. Med. 2018, 378, 449-459. [CrossRef]

49. Turtle, C.J.; Hanafi, L.A.; Berger, C.; Gooley, T.A.; Cherian, S.; Hudecek, M.; Sommermeyer, D.; Melville, K.; Pender, B.; Budiarto, T.M.; et al. CD19 CAR-T cells of defined CD4+:CD8+ composition in adult B cell ALL patients. J. Clin. Invest. 2016, 126, 2123-2138. [CrossRef]

50. Maude, S.L.; Frey, N.; Shaw, P.A.; Aplenc, R.; Barrett, D.M.; Bunin, N.J.; Chew, A.; Gonzalez, V.E.; Zheng, Z.; Lacey, S.F.; et al. Chimeric antigen receptor T cells for sustained remissions in leukemia. N. Engl. J. Med. 2014, 371, 1507-1517. [CrossRef]

51. Laetsch, T.W.; Myers, G.D.; Baruchel, A.; Dietz, A.C.; Pulsipher, M.A.; Bittencourt, H.; Buechner, J.; De Moerloose, B.; Davis, K.L.; Nemecek, E.; et al. Patient-reported quality of life after tisagenlecleucel infusion in children and young adults with relapsed or refractory B-cell acute lymphoblastic leukaemia: A global, single-arm, phase 2 trial. Lancet Oncol. 2019, 20, 1710-1718. [CrossRef]

52. Kantarjian, H.M.; DeAngelo, D.J.; Stelljes, M.; Martinelli, G.; Liedtke, M.; Stock, W.; Gökbuget, N.; O’Brien, S.; Wang, K.; Wang, T.; et al. Inotuzumab Ozogamicin versus Standard Therapy for Acute Lymphoblastic Leukemia. N. Engl. J. Med. 2016, 375, 740-753. [CrossRef] [PubMed]

53. Qin, H.; Ramakrishna, S.; Nguyen, S.; Fountaine, T.J.; Ponduri, A.; Stetler-Stevenson, M.; Yuan, C.M.; Haso, W.; Shern, J.F.; Shah, N.N.; et al. Preclinical Development of Bivalent Chimeric Antigen Receptors Targeting Both CD19 and CD22. Mol. Ther. Oncolytics 2018, 11, 127-137. [CrossRef] [PubMed]

54. Schneider, D.; Xiong, Y.; Wu, D.; Nölle, V.; Schmitz, S.; Haso, W.; Kaiser, A.; Dropulic, B.; Orentas, R.J. A tandem CD19/CD20 CAR lentiviral vector drives on-target and off-target antigen modulation in leukemia cell lines. J. Immunother. Cancer 2017, 5, 42. [CrossRef]

55. Sehn, L.H. Paramount prognostic factors that guide therapeutic strategies in diffuse large B-cell lymphoma. Hematol. Am. Soc. Hematol. Educ. Program 2012, 2012, 402-409. [CrossRef]

56. Sehn, L.H.; Gascoyne, R.D. Diffuse large B-cell lymphoma: Optimizing outcome in the context of clinical and biologic heterogeneity. Blood 2015, 125, 22-32. [CrossRef]

57. Crump, M.; Neelapu, S.S.; Farooq, U.; Van Den Neste, E.; Kuruvilla, J.; Westin, J.; Link, B.K.; Hay, A.; Cerhan, J.R.; Zhu, L.; et al. Outcomes in refractory diffuse large B-cell lymphoma: Results from the international SCHOLAR-1 study. Blood 2017, 130, 1800-1808. [CrossRef] 
58. Schuster, S.J.; Svoboda, J.; Chong, E.A.; Nasta, S.D.; Mato, A.R.; Anak, Ö.; Brogdon, J.L.; Pruteanu-Malinici, I.; Bhoj, V.; Landsburg, D.; et al. Chimeric Antigen Receptor T Cells in Refractory B-Cell Lymphomas. N. Engl. J. Med. 2017, 377, 2545-2554. [CrossRef]

59. Schuster, S.J.; Bishop, M.R.; Tam, C.; Borchmann, P.; Jaeger, U.; Waller, E.K.; Holte, H.; McGuirk, J.P.; Jaglowski, S.; Tobinai, K.; et al. Sustained Disease Control for Adult Patients with Relapsed or Refractory Diffuse Large B-Cell Lymphoma: An Updated Analysis of Juliet, a Global Pivotal Phase 2 Trial of Tisagenlecleucel. Blood 2018, 132, 1684. [CrossRef]

60. Locke, F.L.; Neelapu, S.S.; Bartlett, N.L.; Siddiqi, T.; Chavez, J.C.; Hosing, C.M.; Ghobadi, A.; Budde, L.E.; Bot, A.; Rossi, J.M.; et al. Phase 1 Results of ZUMA-1: A Multicenter Study of KTE-C19 Anti-CD19 CAR T Cell Therapy in Refractory Aggressive Lymphoma. Mol. Ther. 2017, 25, 285-295. [CrossRef]

61. Neelapu, S.S.; Ghobadi, A.; Jacobson, C.A.; Miklos, D.B.; Lekakis, L.J.; Oluwole, O.O.; Lin, Y.; Braunschweig, I.; Hill, B.T.; Timmerman, J.M.; et al. 2-Year Follow-up and High-Risk Subset Analysis of Zuma-1, the Pivotal Study of Axicabtagene Ciloleucel (Axi-Cel) in Patients with Refractory Large B Cell Lymphoma. Blood 2018, 132, 2967. [CrossRef]

62. Locke, F.L.; Ghobadi, A.; Jacobson, C.A.; Miklos, D.B.; Lekakis, L.J.; Oluwole, O.O.; Lin, Y.; Braunschweig, I.; Hill, B.T.; Timmerman, J.M.; et al. Long-term safety and activity of axicabtagene ciloleucel in refractory large B-cell lymphoma (ZUMA-1): A single-arm, multicentre, phase 1-2 trial. Lancet Oncol. 2019, 20, 31-42. [CrossRef]

63. Chow, V.A.; Gopal, A.K.; Maloney, D.G.; Turtle, C.J.; Smith, S.D.; Ujjani, C.S.; Shadman, M.; Cassaday, R.D.; Till, B.G.; Tseng, Y.D.; et al. Outcomes of patients with large B-cell lymphomas and progressive disease following CD19-specific CAR T-cell therapy. Am. J. Hematol. 2019, 94, E209-E213. [CrossRef] [PubMed]

64. Kumar, S.K.; Rajkumar, V.; Kyle, R.A.; van Duin, M.; Sonneveld, P.; Mateos, M.V.; Gay, F.; Anderson, K.C. Multiple myeloma. Nat. Rev. Dis. Primers 2017, 3, 17046. [CrossRef]

65. Mackay, F.; Schneider, P.; Rennert, P.; Browning, J. BAFF AND APRIL: A tutorial on B cell survival. Annu. Rev. Immunol. 2003, 21, 231-264. [CrossRef]

66. Marsters, S.A.; Yan, M.; Pitti, R.M.; Haas, P.E.; Dixit, V.M.; Ashkenazi, A. Interaction of the TNF homologues BLyS and APRIL with the TNF receptor homologues BCMA and TACI. Curr. Biol. 2000, 10, 785-788. [CrossRef]

67. Carpenter, R.O.; Evbuomwan, M.O.; Pittaluga, S.; Rose, J.J.; Raffeld, M.; Yang, S.; Gress, R.E.; Hakim, F.T.; Kochenderfer, J.N. B-cell maturation antigen is a promising target for adoptive T-cell therapy of multiple myeloma. Clin. Cancer. Res. 2013, 19, 2048-2060. [CrossRef]

68. Novak, A.J.; Darce, J.R.; Arendt, B.K.; Harder, B.; Henderson, K.; Kindsvogel, W.; Gross, J.A.; Greipp, P.R.; Jelinek, D.F. Expression of BCMA, TACI, and BAFF-R in multiple myeloma: A mechanism for growth and survival. Blood 2004, 103, 689-694. [CrossRef]

69. Brudno, J.N.; Maric, I.; Hartman, S.D.; Rose, J.J.; Wang, M.; Lam, N.; Stetler-Stevenson, M.; Salem, D.; Yuan, C.; Pavletic, S.; et al. T Cells Genetically Modified to Express an Anti-B-Cell Maturation Antigen Chimeric Antigen Receptor Cause Remissions of Poor-Prognosis Relapsed Multiple Myeloma. J. Clin. Oncol. 2018, 36, 2267-2280. [CrossRef]

70. Mikkilineni, L.; Kochenderfer, J.N. Chimeric antigen receptor T-cell therapies for multiple myeloma. Blood 2017, 130, 2594-2602. [CrossRef]

71. Ali, S.A.; Shi, V.; Maric, I.; Wang, M.; Stroncek, D.F.; Rose, J.J.; Brudno, J.N.; Stetler-Stevenson, M.; Feldman, S.A.; Hansen, B.G.; et al. T cells expressing an anti-B-cell maturation antigen chimeric antigen receptor cause remissions of multiple myeloma. Blood 2016, 128, 1688-1700. [CrossRef] [PubMed]

72. Shah, N.; Chari, A.; Scott, E.; Mezzi, K.; Usmani, S.Z. B-cell maturation antigen (BCMA) in multiple myeloma: Rationale for targeting and current therapeutic approaches. Leukemia 2020, 34, 985-1005. [CrossRef] [PubMed]

73. Cohen, A.D.; Garfall, A.L.; Stadtmauer, E.A.; Melenhorst, J.J.; Lacey, S.F.; Lancaster, E.; Vogl, D.T.; Weiss, B.M.; Dengel, K.; Nelson, A.; et al. B cell maturation antigen-specific CAR T cells are clinically active in multiple myeloma. J. Clin. Investig. 2019, 129, 2210-2221. [CrossRef] [PubMed]

74. Shi, X.; Yan, L.; Shang, J.; Qu, S.; Kang, L.; Zhou, J.; Jin, S.; Yao, W.; Yao, Y.; Yan, S.; et al. Tandom Autologous Transplantation and Combined Infusion of CD19 and Bcma-Specific Chimeric Antigen Receptor T Cells for High Risk MM: Initial Safety and Efficacy Report from a Clinical Pilot Study. Blood 2018, 132, 1009. [CrossRef] 
75. Green, D.J.; Pont, M.; Sather, B.D.; Cowan, A.J.; Turtle, C.J.; Till, B.G.; Nagengast, A.M.; Libby, E.N., III; Becker, P.S.; Coffey, D.G.; et al. Fully Human Bcma Targeted Chimeric Antigen Receptor T Cells Administered in a Defined Composition Demonstrate Potency at Low Doses in Advanced Stage High Risk Multiple Myeloma. Blood 2018, 132, 1011. [CrossRef]

76. Liu, Y.; Chen, Z.; Fang, H.; Wei, R.; Yu, K.; Jiang, S.; Fu, W.; Jiang, H.; Du, J.; He, F.; et al. Durable Remission Achieved from Bcma-Directed CAR-T Therapy Against Relapsed or Refractory Multiple Myeloma. Blood 2018, 132, 956. [CrossRef]

77. Han, L.; Gao, Q.; Zhou, K.; Yin, Q.; Fang, B.; Zhou, J.; Zhu, X.; Liu, D.; Zhang, J.; Du, H.; et al. Development and Evaluation of CART Targeting Bcma with Humanized Alpaca-Derived Single-Domain Antibody As Antigen Recognition Domain. Blood 2018, 132, 1976. [CrossRef]

78. Gregory, T.; Cohen, A.D.; Costello, C.L.; Ali, S.A.; Berdeja, J.G.; Ostertag, E.M.; Martin, C.; Shedlock, D.J.; Resler, M.L.; Spear, M.A.; et al. Efficacy and Safety of P-Bcma-101 CAR-T Cells in Patients with Relapsed/Refractory (r/r) Multiple Myeloma (MM). Blood 2018, 132, 1012. [CrossRef]

79. Bezverbnaya, K.; Lau, V.; Aarts, C.; Denisova, G.; Afsahi, A.; Evelegh, C.; Cummings, D.; Helsen, C.; Bramson, J. T Cells Engineered with a Novel Chimeric Receptor Demonstrate Durable In Vivo Efficacy Against Disseminated Multiple Myeloma. Blood 2018, 132, 962. [CrossRef]

80. Shah, N.; Alsina, M.; Siegel, D.S.; Jagannath, S.; Madduri, D.; Kaufman, J.L.; Turka, A.; Lam, L.P.; Massaro, M.; Hege, K.; et al. Initial Results from a Phase 1 Clinical Study of bb21217, a Next-Generation Anti Bcma CAR T Therapy. Blood 2018, 132, 488. [CrossRef]

81. Laurent, S.A.; Hoffmann, F.S.; Kuhn, P.-H.; Cheng, Q.; Chu, Y.; Schmidt-Supprian, M.; Hauck, S.M.; Schuh, E.; Krumbholz, M.; Rübsamen, H.; et al. $\gamma$-secretase directly sheds the survival receptor BCMA from plasma cells. Nat. Commun. 2015, 6, 7333. [CrossRef] [PubMed]

82. Porter, D.L.; Levine, B.L.; Kalos, M.; Bagg, A.; June, C.H. Chimeric antigen receptor-modified T cells in chronic lymphoid leukemia. N. Engl. J. Med. 2011, 365, 725-733. [CrossRef] [PubMed]

83. Porter, D.L.; Hwang, W.T.; Frey, N.V.; Lacey, S.F.; Shaw, P.A.; Loren, A.W.; Bagg, A.; Marcucci, K.T.; Shen, A.; Gonzalez, V.; et al. Chimeric antigen receptor T cells persist and induce sustained remissions in relapsed refractory chronic lymphocytic leukemia. Sci. Transl. Med. 2015, 7, 303ra139. [CrossRef]

84. Kochenderfer, J.N.; Dudley, M.E.; Carpenter, R.O.; Kassim, S.H.; Rose, J.J.; Telford, W.G.; Hakim, F.T.; Halverson, D.C.; Fowler, D.H.; Hardy, N.M.; et al. Donor-derived CD19-targeted T cells cause regression of malignancy persisting after allogeneic hematopoietic stem cell transplantation. Blood 2013, 122, 4129-4139. [CrossRef] [PubMed]

85. Hoffmann, J.M.; Schubert, M.L.; Wang, L.; Hückelhoven, A.; Sellner, L.; Stock, S.; Schmitt, A.; Kleist, C.; Gern, U.; Loskog, A.; et al. Differences in Expansion Potential of Naive Chimeric Antigen Receptor T Cells from Healthy Donors and Untreated Chronic Lymphocytic Leukemia Patients. Front. Immunol. 2017, 8, 1956. [CrossRef]

86. Riches, J.C.; Davies, J.K.; McClanahan, F.; Fatah, R.; Iqbal, S.; Agrawal, S.; Ramsay, A.G.; Gribben, J.G. $\mathrm{T}$ cells from CLL patients exhibit features of T-cell exhaustion but retain capacity for cytokine production. Blood 2013, 121, 1612-1621. [CrossRef]

87. Lemal, R.; Tournilhac, O. State-of-the-art for CAR T-cell therapy for chronic lymphocytic leukemia in 2019. J. Immunother. Cancer 2019, 7, 202. [CrossRef]

88. Ramos, C.A.; Ballard, B.; Zhang, H.; Dakhova, O.; Gee, A.P.; Mei, Z.; Bilgi, M.; Wu, M.F.; Liu, H.; Grilley, B.; et al. Clinical and immunological responses after CD30-specific chimeric antigen receptor-redirected lymphocytes. J. Clin. Investig. 2017, 127, 3462-3471. [CrossRef]

89. Mardiros, A.; Dos Santos, C.; McDonald, T.; Brown, C.E.; Wang, X.; Budde, L.E.; Hoffman, L.; Aguilar, B.; Chang, W.C.; Bretzlaff, W.; et al. T cells expressing CD123-specific chimeric antigen receptors exhibit specific cytolytic effector functions and antitumor effects against human acute myeloid leukemia. Blood 2013, 122, 3138-3148. [CrossRef]

90. Mardiros, A.; Forman, S.J.; Budde, L.E. T cells expressing CD123 chimeric antigen receptors for treatment of acute myeloid leukemia. Curr. Opin. Hematol. 2015, 22, 484-488. [CrossRef]

91. Ritchie, D.S.; Neeson, P.J.; Khot, A.; Peinert, S.; Tai, T.; Tainton, K.; Chen, K.; Shin, M.; Wall, D.M.; Hönemann, D.; et al. Persistence and efficacy of second generation CAR T cell against the LeY antigen in acute myeloid leukemia. Mol. Ther. 2013, 21, 2122-2129. [CrossRef] [PubMed] 
92. Lynn, R.C.; Poussin, M.; Kalota, A.; Feng, Y.; Low, P.S.; Dimitrov, D.S.; Powell, D.J., Jr. Targeting of folate receptor $\beta$ on acute myeloid leukemia blasts with chimeric antigen receptor-expressing T cells. Blood 2015, 125, 3466-3476. [CrossRef]

93. Kim, M.Y.; Yu, K.R.; Kenderian, S.S.; Ruella, M.; Chen, S.; Shin, T.H.; Aljanahi, A.A.; Schreeder, D.; Klichinsky, M.; Shestova, O.; et al. Genetic Inactivation of CD33 in Hematopoietic Stem Cells to Enable CAR T Cell Immunotherapy for Acute Myeloid Leukemia. Cell 2018, 173, 1439-1453.e1419. [CrossRef] [PubMed]

94. Cummins, K.D.; Gill, S. Will CAR T cell therapy have a role in AML? Promises and pitfalls. Semin. Hematol. 2019, 56, 155-163. [CrossRef] [PubMed]

95. Gill, S.; Tasian, S.K.; Ruella, M.; Shestova, O.; Li, Y.; Porter, D.L.; Carroll, M.; Danet-Desnoyers, G.; Scholler, J.; Grupp, S.A.; et al. Preclinical targeting of human acute myeloid leukemia and myeloablation using chimeric antigen receptor-modified T cells. Blood 2014, 123, 2343-2354. [CrossRef]

96. Petrov, J.C.; Wada, M.; Pinz, K.G.; Yan, L.E.; Chen, K.H.; Shuai, X.; Liu, H.; Chen, X.; Leung, L.H.; Salman, H.; et al. Compound CAR T-cells as a double-pronged approach for treating acute myeloid leukemia. Leukemia 2018, 32, 1317-1326. [CrossRef]

97. Mardiana, S.; Gill, S. CAR T Cells for Acute Myeloid Leukemia: State of the Art and Future Directions. Front. Oncol. 2020, 10. [CrossRef]

98. Bordignon, C.; Bonini, C.; Verzeletti, S.; Nobili, N.; Maggioni, D.; Traversari, C.; Giavazzi, R.; Servida, P.; Zappone, E.; Benazzi, E.; et al. Transfer of the HSV-tk gene into donor peripheral blood lymphocytes for in vivo modulation of donor anti-tumor immunity after allogeneic bone marrow transplantation. Hum. Gene Ther. 1995, 6, 813-819. [CrossRef]

99. Gargett, T.; Brown, M.P. The inducible caspase-9 suicide gene system as a "safety switch" to limit on-target, off-tumor toxicities of chimeric antigen receptor T cells. Front. Pharmacol. 2014, 5, 235. [CrossRef]

100. Hoyos, V.; Savoldo, B.; Quintarelli, C.; Mahendravada, A.; Zhang, M.; Vera, J.; Heslop, H.E.; Rooney, C.M.; Brenner, M.K.; Dotti, G. Engineering CD19-specific T lymphocytes with interleukin-15 and a suicide gene to enhance their anti-lymphoma/leukemia effects and safety. Leukemia 2010, 24, 1160-1170. [CrossRef]

101. Li, H.; Zhao, Y. Increasing the safety and efficacy of chimeric antigen receptor T cell therapy. Protein Cell 2017, 8, 573-589. [CrossRef]

102. Ali, R.; Ramdial, J.; Algaze, S.; Beitinjaneh, A. The Role of Anti-Thymocyte Globulin or Alemtuzumab-Based Serotherapy in the Prophylaxis and Management of Graft-Versus-Host Disease. Biomedicines 2017, 5, 67. [CrossRef]

103. Zhao, Z.; Condomines, M.; van der Stegen, S.J.C.; Perna, F.; Kloss, C.C.; Gunset, G.; Plotkin, J.; Sadelain, M. Structural Design of Engineered Costimulation Determines Tumor Rejection Kinetics and Persistence of CAR T Cells. Cancer Cell 2015, 28, 415-428. [CrossRef] [PubMed]

104. Kenderian, S.S.; June, C.H.; Gill, S. Generating and Expanding Autologous Chimeric Antigen Receptor T Cells from Patients with Acute Myeloid Leukemia. Methods Mol. Biol. 2017, 1633, 267. [CrossRef] [PubMed]

105. Cummins, K.D.; Frey, N.; Nelson, A.M.; Schmidt, A.; Luger, S.; Isaacs, R.E.; Lacey, S.F.; Hexner, E.; Melenhorst, J.J.; June, C.H.; et al. Treating Relapsed/Refractory (RR) AML with Biodegradable Anti-CD123 CAR Modified T Cells. Blood 2017, 130, 1359. [CrossRef]

106. Brudno, J.N.; Kochenderfer, J.N. Recent advances in CAR T-cell toxicity: Mechanisms, manifestations and management. Blood Rev. 2019, 34, 45-55. [CrossRef] [PubMed]

107. Lin, W.Y.; Chen, Y.W.; Lin, C.F.; Yang, Y.P.; Wang, M.L.; Hung, K.F.; Huang, P.I.; Lee, Y.Y.; Chiou, S.H. Emerging trends in gene-modified-based chimeric antigen receptor-engineered T-cellular therapy for malignant tumors: The lesson from leukemia to pediatric brain tumors. J. Chin. Med. Assoc. 2020, 83, 719-724. [CrossRef]

108. Azoulay, E.; Darmon, M.; Valade, S. Acute life-threatening toxicity from CAR T-cell therapy. Intensive Care Med. 2020, 46, 1723-1726. [CrossRef]

109. Lee, D.W.; Santomasso, B.D.; Locke, F.L.; Ghobadi, A.; Turtle, C.J.; Brudno, J.N.; Maus, M.V.; Park, J.H.; Mead, E.; Pavletic, S.; et al. ASTCT Consensus Grading for Cytokine Release Syndrome and Neurologic Toxicity Associated with Immune Effector Cells. Biol. Blood Marrow Transplant. 2019, 25, 625-638. [CrossRef]

110. Frey, N.; Porter, D. Cytokine Release Syndrome with Chimeric Antigen Receptor T Cell Therapy. Biol. Blood Marrow Transplant. 2019, 25, e123-e127. [CrossRef]

111. Neelapu, S.S.; Tummala, S.; Kebriaei, P.; Wierda, W.; Gutierrez, C.; Locke, F.L.; Komanduri, K.V.; Lin, Y.; Jain, N.; Daver, N.; et al. Chimeric antigen receptor T-cell therapy-assessment and management of toxicities. Nat. Rev. Clin. Oncol. 2018, 15, 47-62. [CrossRef] [PubMed] 
112. Hay, K.A.; Hanafi, L.A.; Li, D.; Gust, J.; Liles, W.C.; Wurfel, M.M.; López, J.A.; Chen, J.; Chung, D.; Harju-Baker, S.; et al. Kinetics and biomarkers of severe cytokine release syndrome after CD19 chimeric antigen receptor-modified T-cell therapy. Blood 2017, 130, 2295-2306. [CrossRef] [PubMed]

113. Jin, Z.; Xiang, R.; Qing, K.; Li, X.; Zhang, Y.; Wang, L.; Zhu, H.; Mao, Y.; Xu, Z.; Li, J. The severe cytokine release syndrome in phase I trials of CD19-CAR-T cell therapy: A systematic review. Ann. Hematol. 2018, 97, 1327-1335. [CrossRef] [PubMed]

114. Gil, L.; Łojko-Dankowska, A.; Matuszak, M.; Wache, A.; Nowicki, A.; Graduszewska, A.; Niezgoda, A.; Dytfeld, D. CAR-T cell therapy-toxicity and its management. Acta Haematol. Pol. 2020, 51, 6. [CrossRef]

115. Sievers, S.; Watson, G.; Johncy, S.; Adkins, S. Recognizing and Grading CAR T-Cell Toxicities: An Advanced Practitioner Perspective. Front. Oncol. 2020, 10. [CrossRef]

116. Turtle, C.J.; Hay, K.A.; Hanafi, L.A.; Li, D.; Cherian, S.; Chen, X.; Wood, B.; Lozanski, A.; Byrd, J.C.; Heimfeld, S.; et al. Durable Molecular Remissions in Chronic Lymphocytic Leukemia Treated With CD19-Specific Chimeric Antigen Receptor-Modified T Cells After Failure of Ibrutinib. J. Clin. Oncol. 2017, 35, 3010-3020. [CrossRef]

117. Gust, J.; Taraseviciute, A.; Turtle, C.J. Neurotoxicity Associated with CD19-Targeted CAR-T Cell Therapies. CNS Drugs 2018, 32, 1091-1101. [CrossRef]

118. Taraseviciute, A.; Tkachev, V.; Ponce, R.; Turtle, C.J.; Snyder, J.M.; Liggitt, H.D.; Myerson, D.; Gonzalez-Cuyar, L.; Baldessari, A.; English, C.; et al. Chimeric Antigen Receptor T Cell-Mediated Neurotoxicity in Nonhuman Primates. Cancer Discov. 2018, 8, 750-763. [CrossRef]

119. Santomasso, B.D.; Park, J.H.; Salloum, D.; Riviere, I.; Flynn, J.; Mead, E.; Halton, E.; Wang, X.; Senechal, B.; Purdon, T.; et al. Clinical and Biological Correlates of Neurotoxicity Associated with CAR T-cell Therapy in Patients with B-cell Acute Lymphoblastic Leukemia. Cancer Discov. 2018, 8, 958-971. [CrossRef]

120. Gust, J.; Hay, K.A.; Hanafi, L.A.; Li, D.; Myerson, D.; Gonzalez-Cuyar, L.F.; Yeung, C.; Liles, W.C.; Wurfel, M.; Lopez, J.A.; et al. Endothelial Activation and Blood-Brain Barrier Disruption in Neurotoxicity after Adoptive Immunotherapy with CD19 CAR-T Cells. Cancer Discov. 2017, 7, 1404-1419. [CrossRef]

121. Berdeja, J.G.; Lin, Y.; Raje, N.; Munshi, N.; Siegel, D.; Liedtke, M.; Jagannath, S.; Maus, M.V.; Turka, A.; Lam, L.P.; et al. Durable Clinical Responses in Heavily Pretreated Patients with Relapsed/Refractory Multiple Myeloma: Updated Results from a Multicenter Study of bb2121 Anti-Bcma CAR T Cell Therapy. Blood 2017, 130, 740. [CrossRef]

122. Shalabi, H.; Wolters, P.L.; Martin, S.; Toledo-Tamula, M.A.; Roderick, M.C.; Struemph, K.; Kane, E.; Yates, B.; Delbrook, C.; Mackall, C.L.; et al. Systematic Evaluation of Neurotoxicity in Children and Young Adults Undergoing CD22 Chimeric Antigen Receptor T-Cell Therapy. J. Immunother. 2018, 41, 350-358. [CrossRef] [PubMed]

123. Whiteside, T.L. Immune cells in the tumor microenvironment. Mechanisms responsible for functional and signaling defects. Adv. Exp. Med. Biol. 1998, 451, 167-171. [PubMed]

124. Andersen, M.H. The targeting of immunosuppressive mechanisms in hematological malignancies. Leukemia 2014, 28, 1784-1792. [CrossRef]

125. Xu, X.; Sun, Q.; Liang, X.; Chen, Z.; Zhang, X.; Zhou, X.; Li, M.; Tu, H.; Liu, Y.; Tu, S.; et al. Mechanisms of Relapse After CD19 CAR T-Cell Therapy for Acute Lymphoblastic Leukemia and Its Prevention and Treatment Strategies. Front. Immunol. 2019, 10, 2664. [CrossRef]

126. Schumann, K.; Lin, S.; Boyer, E.; Simeonov, D.R.; Subramaniam, M.; Gate, R.E.; Haliburton, G.E.; Ye, C.J.; Bluestone, J.A.; Doudna, J.A.; et al. Generation of knock-in primary human T cells using Cas9 ribonucleoproteins. Proc. Natl. Acad. Sci. USA 2015, 112, 10437-10442. [CrossRef]

127. Hu, B.; Zou, Y.; Zhang, L.; Tang, J.; Niedermann, G.; Firat, E.; Huang, X.; Zhu, X. Nucleofection with Plasmid DNA for CRISPR/Cas9-Mediated Inactivation of Programmed Cell Death Protein 1 in CD133-Specific CAR T Cells. Hum. Gene Ther. 2019, 30, 446-458. [CrossRef]

128. Cherkassky, L.; Morello, A.; Villena-Vargas, J.; Feng, Y.; Dimitrov, D.S.; Jones, D.R.; Sadelain, M.; Adusumilli, P.S. Human CAR T cells with cell-intrinsic PD-1 checkpoint blockade resist tumor-mediated inhibition. J. Clin. Investig. 2016, 126, 3130-3144. [CrossRef]

129. Rafiq, S.; Yeku, O.O.; Jackson, H.J.; Purdon, T.J.; van Leeuwen, D.G.; Drakes, D.J.; Song, M.; Miele, M.M.; Li, Z.; Wang, P.; et al. Targeted delivery of a PD-1-blocking scFv by CAR-T cells enhances anti-tumor efficacy in vivo. Nat. Biotechnol. 2018, 36, 847-856. [CrossRef]

130. Ren, J.; Zhang, X.; Liu, X.; Fang, C.; Jiang, S.; June, C.H.; Zhao, Y. A versatile system for rapid multiplex genome-edited CAR T cell generation. Oncotarget 2017, 8, 17002-17011. [CrossRef] 
131. Singh, H.; Figliola, M.J.; Dawson, M.J.; Olivares, S.; Zhang, L.; Yang, G.; Maiti, S.; Manuri, P.; Senyukov, V.; Jena, B.; et al. Manufacture of clinical-grade CD19-specific T cells stably expressing chimeric antigen receptor using Sleeping Beauty system and artificial antigen presenting cells. PLoS ONE 2013, 8, e64138. [CrossRef] [PubMed]

132. Singh, H.; Figliola, M.J.; Dawson, M.J.; Huls, H.; Olivares, S.; Switzer, K.; Mi, T.; Maiti, S.; Kebriaei, P.; Lee, D.A.; et al. Reprogramming CD19-specific T cells with IL-21 signaling can improve adoptive immunotherapy of B-lineage malignancies. Cancer Res. 2011, 71, 3516-3527. [CrossRef] [PubMed]

133. Jacobson, C.A.; Locke, F.L.; Miklos, D.B.; Herrera, A.F.; Westin, J.R.; Lee, J.; Rossi, J.M.; Zheng, L.; Avanzi, M.P.; Roberts, Z.J.; et al. End of Phase 1 Results from Zuma-6: Axicabtagene Ciloleucel (Axi-Cel) in Combination with Atezolizumab for the Treatment of Patients with Refractory Diffuse Large B Cell Lymphoma. Blood 2018, 132, 4192. [CrossRef]

134. Siddiqi, T.; Abramson, J.S.; Lee, H.J.; Schuster, S.; Hasskarl, J.; Montheard, S.; Dell Aringa, J.; Thompson, E.; Ananthakrishnan, R.; Lunning, M. Safety of lisocabtagene maraleucel given with durvalumab in patients with relapsed/refractory aggressive b-cell non hodgkin lymphoma: First results from the platform study. Hematol. Oncol. 2019, 37, 171-172. [CrossRef]

135. Cao, Y.; Lu, W.; Sun, R.; Jin, X.; Cheng, L.; He, X.; Wang, L.; Yuan, T.; Lyu, C.; Zhao, M. Anti-CD19 Chimeric Antigen Receptor T Cells in Combination with Nivolumab Are Safe and Effective Against Relapsed/Refractory B-Cell Non-hodgkin Lymphoma. Front. Oncol. 2019, 9, 767. [CrossRef]

136. Rupp, L.J.; Schumann, K.; Roybal, K.T.; Gate, R.E.; Ye, C.J.; Lim, W.A.; Marson, A. CRISPR/Cas9-mediated PD-1 disruption enhances anti-tumor efficacy of human chimeric antigen receptor T cells. Sci. Rep. 2017, 7, 737. [CrossRef]

137. Zou, W.; Chen, L. Inhibitory B7-family molecules in the tumour microenvironment. Nat. Rev. Immunol. 2008, 8, 467-477. [CrossRef]

138. Wang, X.; Walter, M.; Urak, R.; Weng, L.; Huynh, C.; Lim, L.; Wong, C.W.; Chang, W.C.; Thomas, S.H.; Sanchez, J.F.; et al. Lenalidomide Enhances the Function of CS1 Chimeric Antigen Receptor-Redirected T Cells Against Multiple Myeloma. Clin. Cancer. Res. 2018, 24, 106-119. [CrossRef]

139. Torres-Collado, A.X.; Jazirehi, A.R. Overcoming Resistance of Human Non-Hodgkin's Lymphoma to CD19-CAR CTL Therapy by Celecoxib and Histone Deacetylase Inhibitors. Cancers (Basel) 2018, 10, 200. [CrossRef]

140. Frey, N.V. Chimeric antigen receptor T cells for acute lymphoblastic leukemia. Am. J. Hematol. 2019, 94, S24-S27. [CrossRef]

141. Summers, C.; Annesley, C.; Bleakley, M.; Dahlberg, A.; Jensen, M.C.; Gardner, R. Long Term Follow-up after SCRI-CAR19v1 Reveals Late Recurrences As Well As a Survival Advantage to Consolidation with HCT after CAR T Cell Induced Remission. Blood 2018, 132, 967. [CrossRef]

142. Boissel, L.; Betancur, M.; Wels, W.S.; Tuncer, H.; Klingemann, H. Transfection with mRNA for CD19 specific chimeric antigen receptor restores NK cell mediated killing of CLL cells. Leuk. Res. 2009, 33, 1255-1259. [CrossRef]

143. Boissel, L.; Betancur, M.; Lu, W.; Wels, W.S.; Marino, T.; Van Etten, R.A.; Klingemann, H. Comparison of mRNA and lentiviral based transfection of natural killer cells with chimeric antigen receptors recognizing lymphoid antigens. Leuk. Lymphoma 2012, 53, 958-965. [CrossRef] [PubMed]

144. Romanski, A.; Uherek, C.; Bug, G.; Seifried, E.; Klingemann, H.; Wels, W.S.; Ottmann, O.G.; Tonn, T. CD19-CAR engineered NK-92 cells are sufficient to overcome NK cell resistance in B-cell malignancies. J. Cell. Mol. Med. 2016, 20, 1287-1294. [CrossRef] [PubMed]

145. Oelsner, S.; Friede, M.E.; Zhang, C.; Wagner, J.; Badura, S.; Bader, P.; Ullrich, E.; Ottmann, O.G.; Klingemann, H.; Tonn, T.; et al. Continuously expanding CAR NK-92 cells display selective cytotoxicity against B-cell leukemia and lymphoma. Cytotherapy 2017, 19, 235-249. [CrossRef] [PubMed]

146. Shimasaki, N.; Fujisaki, H.; Cho, D.; Masselli, M.; Lockey, T.; Eldridge, P.; Leung, W.; Campana, D. A clinically adaptable method to enhance the cytotoxicity of natural killer cells against B-cell malignancies. Cytotherapy 2012, 14, 830-840. [CrossRef] [PubMed]

147. Chu, J.; Deng, Y.; Benson, D.M.; He, S.; Hughes, T.; Zhang, J.; Peng, Y.; Mao, H.; Yi, L.; Ghoshal, K.; et al. CS1-specific chimeric antigen receptor (CAR)-engineered natural killer cells enhance in vitro and in vivo antitumor activity against human multiple myeloma. Leukemia 2014, 28, 917-927. [CrossRef] 
148. Avanzi, M.P.; Yeku, O.; Li, X.; Wijewarnasuriya, D.P.; van Leeuwen, D.G.; Cheung, K.; Park, H.; Purdon, T.J.; Daniyan, A.F.; Spitzer, M.H.; et al. Engineered Tumor-Targeted T Cells Mediate Enhanced Anti-Tumor Efficacy Both Directly and through Activation of the Endogenous Immune System. Cell Rep. 2018, 23, 2130-2141. [CrossRef]

149. Yeku, O.O.; Brentjens, R.J. Armored CAR T-cells: Utilizing cytokines and pro-inflammatory ligands to enhance CAR T-cell anti-tumour efficacy. Biochem. Soc. Trans. 2016, 44, 412-418. [CrossRef]

150. Titov, A.; Valiullina, A.; Zmievskaya, E.; Zaikova, E.; Petukhov, A.; Miftakhova, R.; Bulatov, E.; Rizvanov, A. Advancing CAR T-Cell Therapy for Solid Tumors: Lessons Learned from Lymphoma Treatment. Cancers (Basel) 2020, 12, 125. [CrossRef]

151. Abel, G.A.; Klepin, H.D. Frailty and the management of hematologic malignancies. Blood 2018, 131, 515-524. [CrossRef] [PubMed]

152. Vormittag, P.; Gunn, R.; Ghorashian, S.; Veraitch, F.S. A guide to manufacturing CAR T cell therapies. Curr. Opin. Biotechnol. 2018, 53, 164-181. [CrossRef] [PubMed]

153. Piscopo, N.J.; Mueller, K.P.; Das, A.; Hematti, P.; Murphy, W.L.; Palecek, S.P.; Capitini, C.M.; Saha, K. Bioengineering Solutions for Manufacturing Challenges in CAR T Cells. Biotechnol. J. 2018, 13. [CrossRef] [PubMed]

Publisher's Note: MDPI stays neutral with regard to jurisdictional claims in published maps and institutional affiliations.

(C) 2020 by the authors. Licensee MDPI, Basel, Switzerland. This article is an open access article distributed under the terms and conditions of the Creative Commons Attribution (CC BY) license (http://creativecommons.org/licenses/by/4.0/). 